\title{
دور تطبيق مبادئ الجودة الشاملة في تحسين أداء المؤسسة دراسة حالة قطب المحروقات بسكيكدة
}

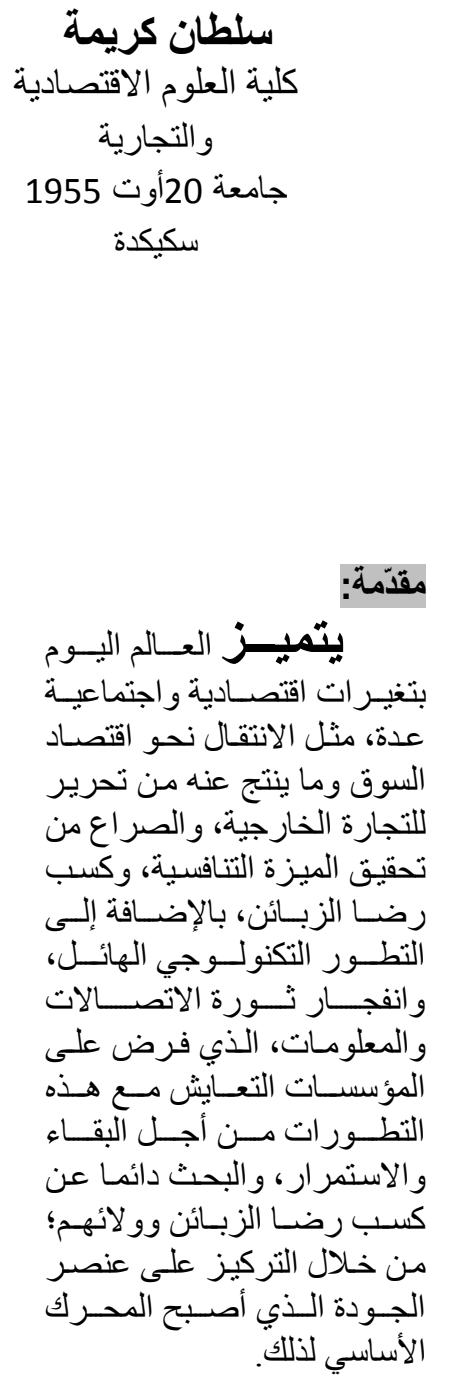

\section{Résumé:}

L'objectif de cette étude est d'identifier la qualité des institutions algériennes, en particulier les institutions des hydrocarbures de la wilaya de Skikda, en appliquant les principes les plus importants de gestion de la qualité totale, puis de tester la relation entre ces principes et la performance globale des institutions.

Pour recueillir des données, un questionnaire a été préparé en utilisant les études pertinentes. L'étude a atteint un certain nombre de résultats, notamment: - Il y a un certain intérêt pour la qualité Par les institutions d'hydrocarbures de la wilaya de skikda, Ceci est illustré par les réponses des répondants aux principes de qualité. - En testant les hypothèses de l'étude, il y avait une relation statistiquement significative entre les principes de TQM et la performance de l'établissement. Mots-clés: qualité, principes de la gestion de la qualité totale, performance de l'organisation 
ومن أجل مواجهة التطور ات السريعة والاستحو اذ على أكبر حصة من السوق، كانت الدول

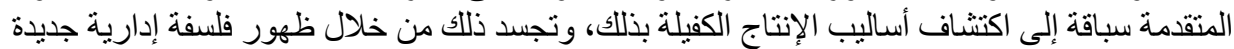

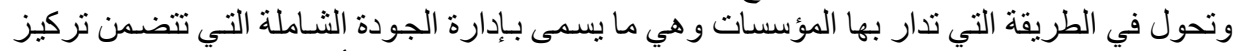

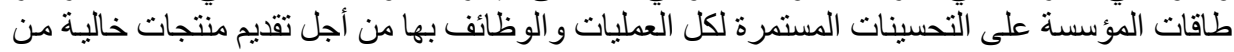

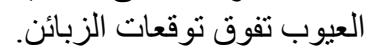

كانت الجودة في السابق تخص الزئن المنتج النهائي فقط و لا تتعدى الوظيفة الإنتاجية و أصبحت حاليا تخص

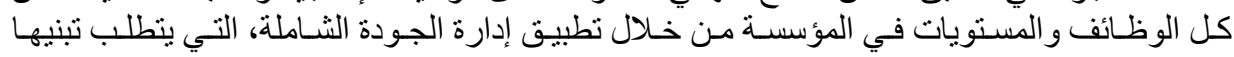
تغيير ات جذرية وشاملة ومستمرة في كافة النشاطات

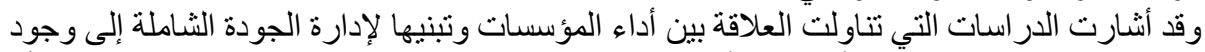

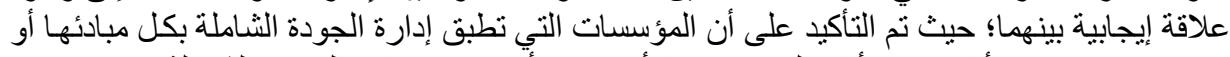

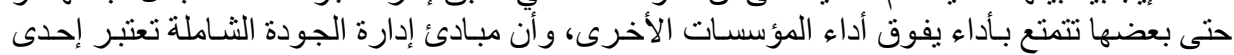

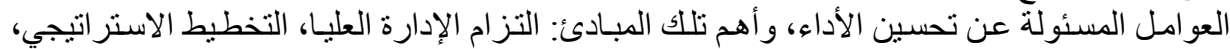
ثثافة الجودة، الاهتمام بالعمال، التركيز على الزئل الزائن و التحسين المستمر للجودة....

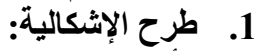

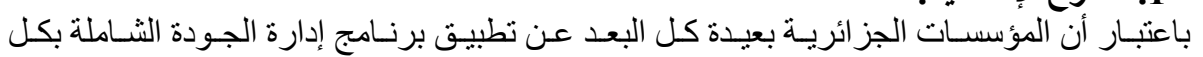

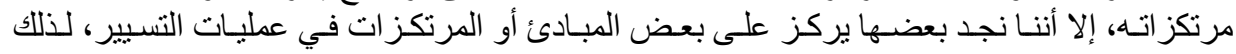

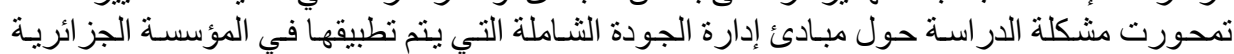

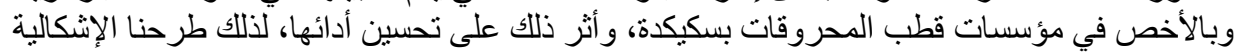

مـا مـدى مسـاهمة تطبيقت مبـادئ إدارة الجودة الثـاملة في تحسبن الأداء بمؤسسـات قطب

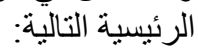

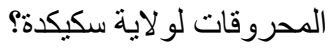

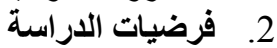

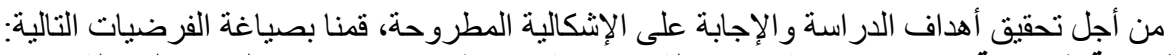

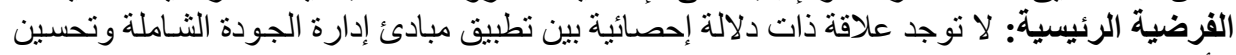

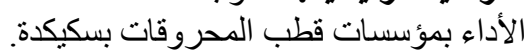

الفرضيات الفر عية: و هي منبنقة من الفرضية الفيكة الرئيسية: لا توجد علاقة ذات دلالة إحصائية بين تطبيق مبدأ التزام الإدارة العليا ولحئ الحسين الأداء بمؤسسات قطب

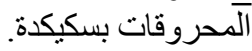
لا توجد علاقة ذات دلالة إحصائية بين تطبيق مبدأ التخطيط الاستر اتيجي وتحسين الأداء بمؤسسات قَّب المحروقات بسكيكدة. لا نوجد علاقة ذات دلاكلة إحصـائية بين نطبيق مبدأ ثقافة الجودة وتحسين الأداء بمؤسسـات قطب الآحروقات بسكيكدة.

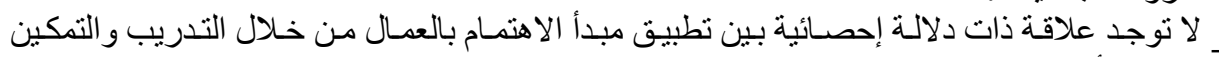

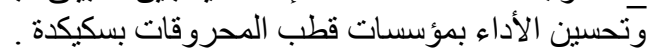

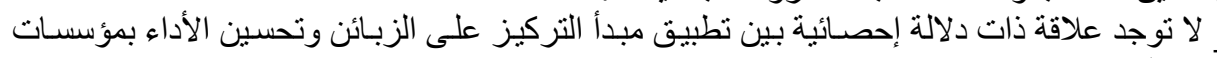
قَّب المحروقات بسكيكدة. لا توجد علاقة ذات دلالة إحصائية بين تطبيق مبدأ التحسين المستمر للجودة وتحسين الأداء بمؤسسات قَطب المحروقات بسكيكدة. 3.أهداف الدراسة:

يصبو هذا البحث إلى تحقيق الأهداف التالية:

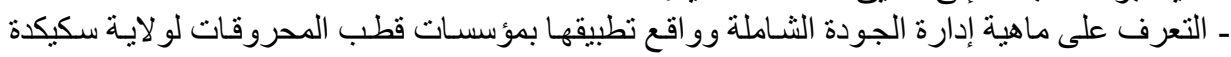
كعينة من المؤسسات الجز ائرية. 
ـ ـ التعرف على ماهية الأداء ومعايير قياسه، ومستويات الأداء الدحققة بالمؤسسات محل الدر اسة.

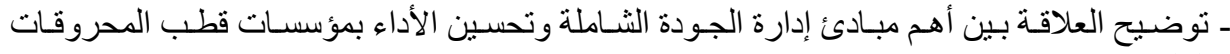
بسكيكدة.

4.منهج ومتغيرات الدراسة: من أجل تحقيق أهداف الدراسة، والإجابة على إثنكالية البحث اعتمدنا على وإلى

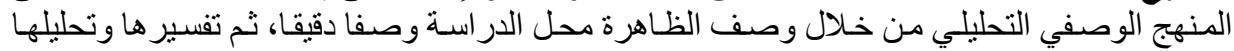

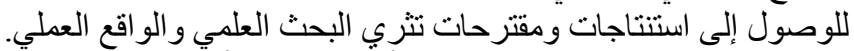

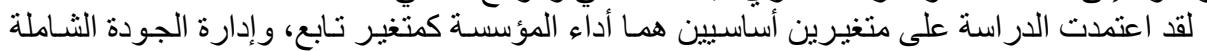

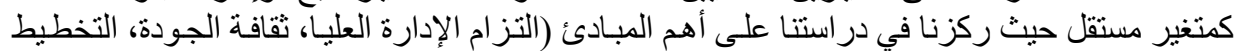

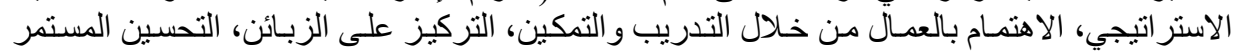

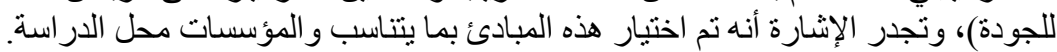

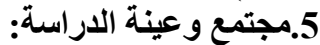

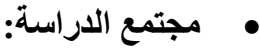

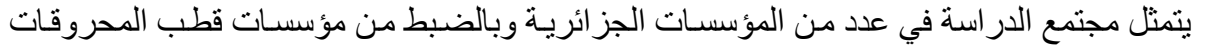

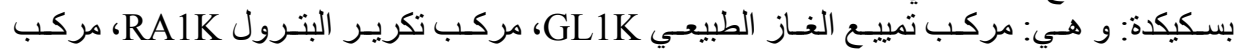
البلاستيك سكيكدة:CP2K2، المديرية الجهويـة للنقل بالأنابيب سكيكدة TRC ومركب تكرول تلكرير المكثفات

.TOPING

$$
\begin{aligned}
& \text { • عينة الدراسة: } \\
& \text { كتتثنل عينة الدراسة في } 169 \text { مفردة من موظفي وإطار ات المؤسسات محل الدراسة. }
\end{aligned}
$$

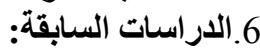

6.6.دراسة بوخلوة باديس بعنوان: "أثر تطبيق مبادئ إدارة الجودة الثـاملة على جودة المنتجات

النفطية"

وقد هدفت الدر اسة إلى الكثف عن أثر تطبيق مبادئ إدارة الجودة الثناملة في مؤسسة سوناطر الك ـ-

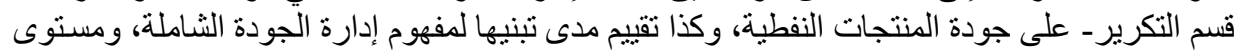

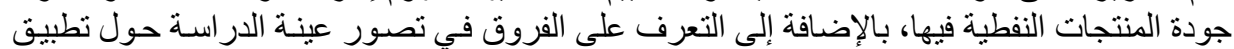

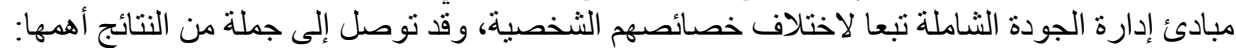

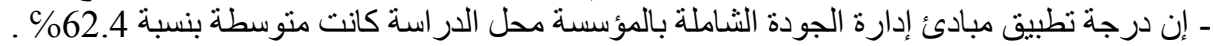

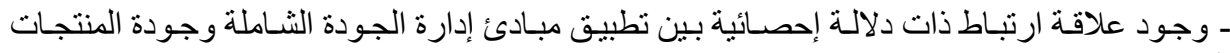
النفطية.

ـ وجود تأثير ذو دلالـة إحصـائية لتطبيق مبـادئ إدارة الجودة الثـاملة مجتمعـة ومنفردة على جودة

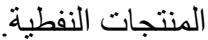

2.6. دراسة مسعود عبد الله بلري (1999): بعنوان: إدارة الجودة وتأثير ها على أداء المنشآت.

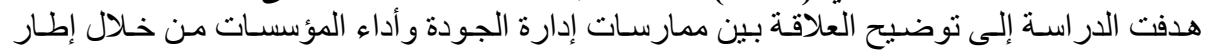

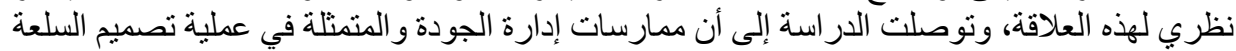

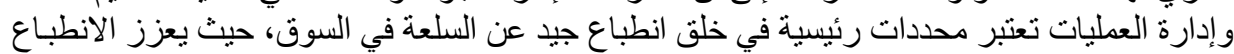

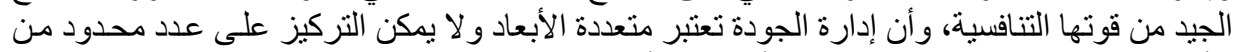

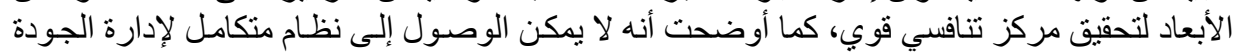

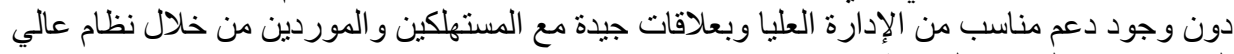
الكفاءة لإدارة المو ارد البشرية.

The effects of TQM " دراسة Esin sadikoglu and Hilal Olkay pratices on performance and the barriers to TQM practices in Türkiye

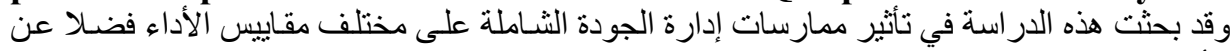

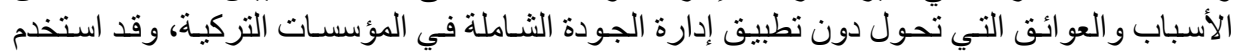


الباحثنان منهجية مسح مستعرضة، وتمت الدراسة على عينة مختارة من المؤسسات الأعضاء في جمعية

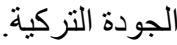

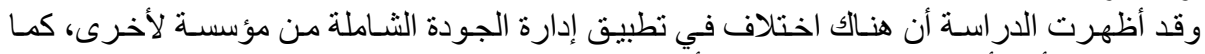

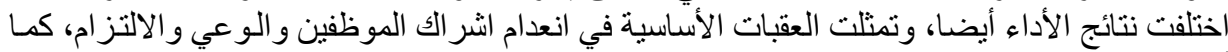
أن هيكل المؤسسات غير مناسب للعاملين.

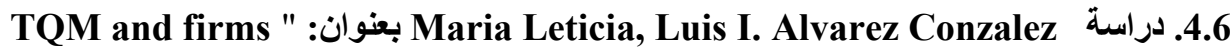
"performance وقد كان الهدف من الدراسة هو تطوير أداة لقياس تطبيق إدارة الجودة الثـاملة في أعقاب النموذج الإدي

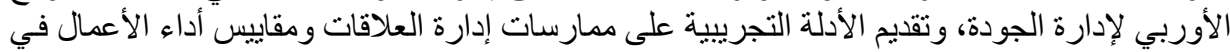

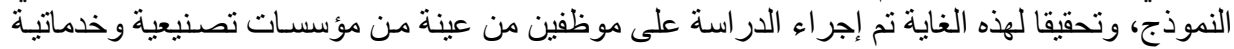

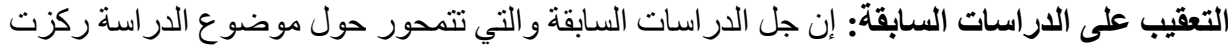

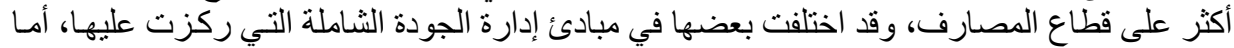

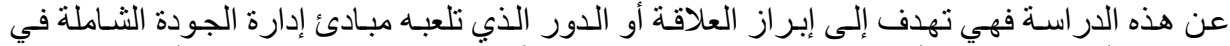

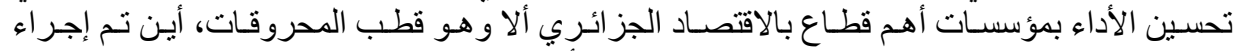
الدراسة على مجمو عة من المؤسسات في نفس القطاع، أين تم اختيار عينة تلتكون من 169 مفردة من الأن الموظفين من هذه المؤسسات.

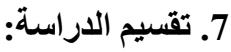

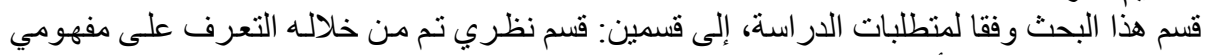

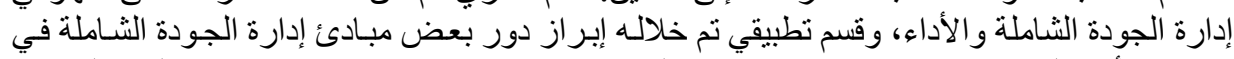

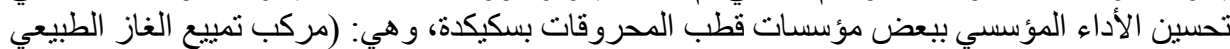

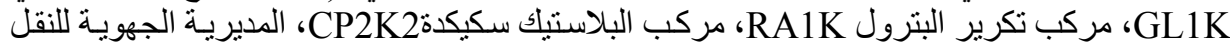

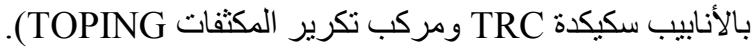
ثانيا: مبادئ إدارة الجودة الثناملة:

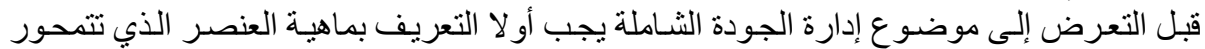

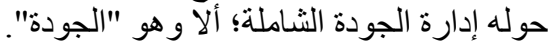

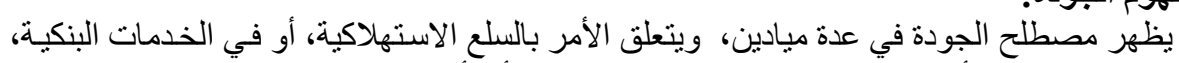

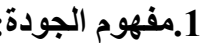

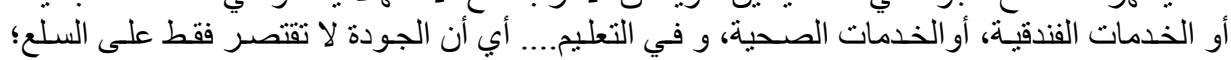
ولكنها تتوسع لتشمل الجانب الخدماتي. أنسات

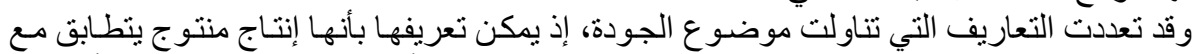

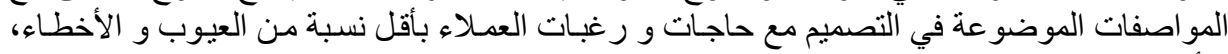
وبأقل تكلفة ممكنة بهدف إرضاء العبورئ العميل.

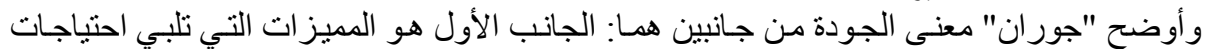

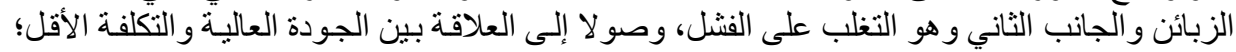
وذللك كما هو موضح في الجدول التالي: 
الجدول (1): الجنى الجودة

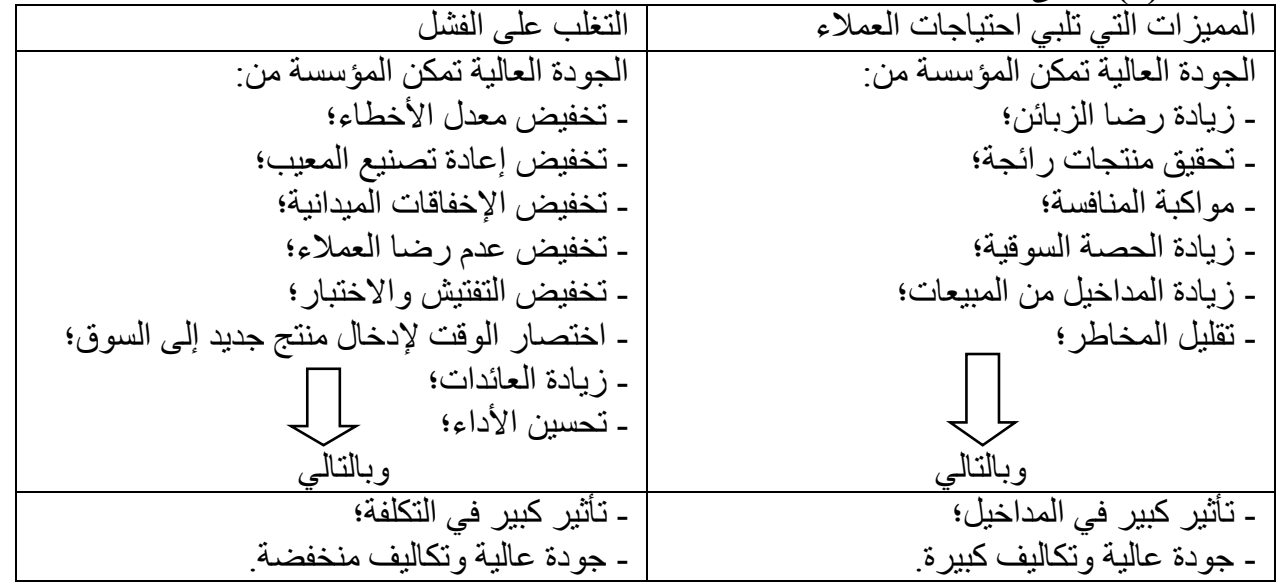

La source:Joseph M . Juran ; Joseph A.Defeo, Juran's quality hand book, « the complete guide to the performance excellence », sixth edition, MC grawhill, p2.2.

2.2. ماهية إدارة الجودة الشاملة وأهم مبادئها:

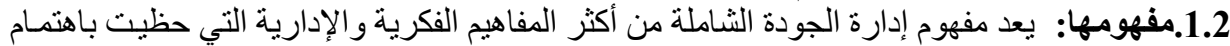

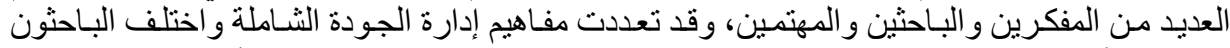

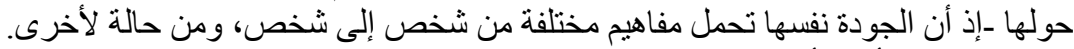

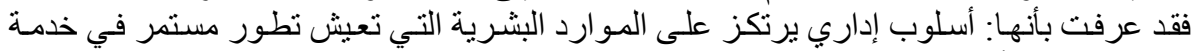

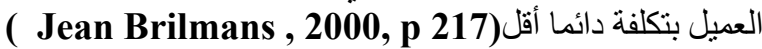

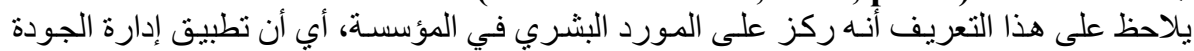

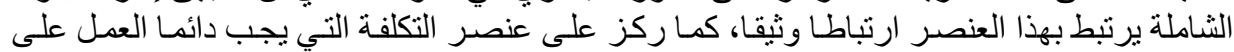
تخفيضها من أجل خدمة العميل بما برضئ برضيه

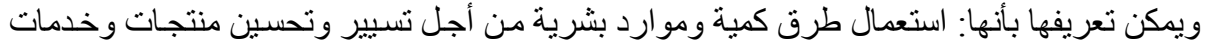

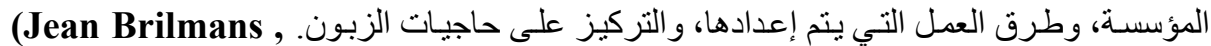

2000, p 217)

وقد عرفها كروسبي (Crosby) كما يلي: "إن إدارة الجودة الثـاملة تمثل المنهجيـة المنظمـة لضـمان

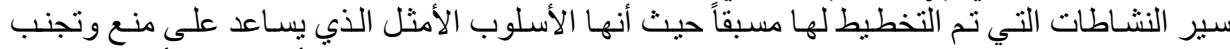

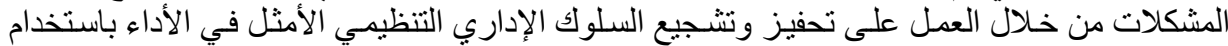

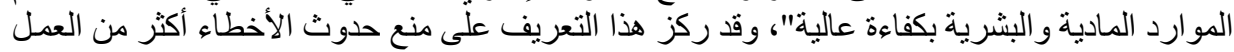
على اكتشافها.

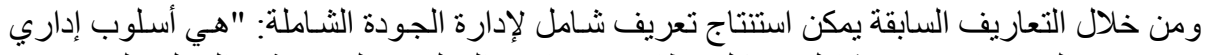

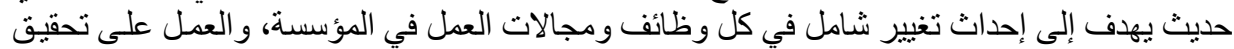

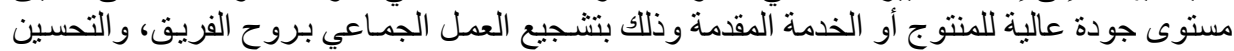

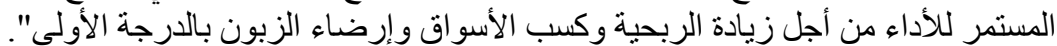

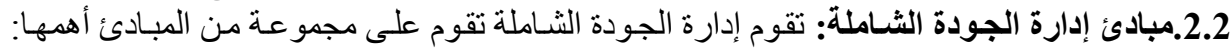

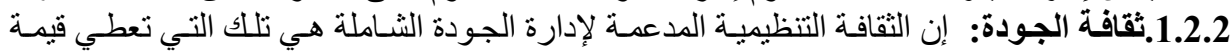
للزبائن و التحسين و عمل الفريق، وهنالك من المؤسسات من يركز على هذه العناصـر فيكون من السـهل 
عليه تغيير الثقافة التنظيمية والتوجه لتطبيق إدارة الجودة الثـاملة؛ و الثقافة يجب أن تلبي مجموعة من

الوظائف:نوين (Hubert K.Rampersad, OPCIT, p274)

• التكامل الداخلي من خلال تتسيق العطليات الداخلية، والتركيز على أنشال التعاون وتبسيطها،

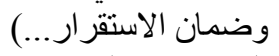

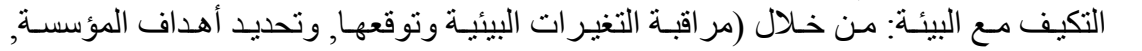

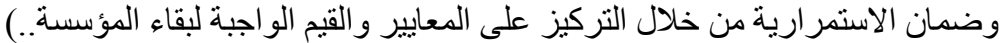

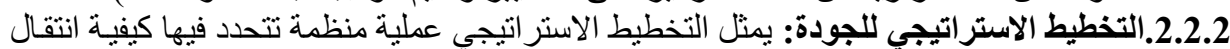

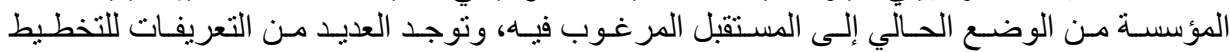

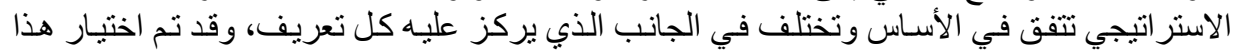

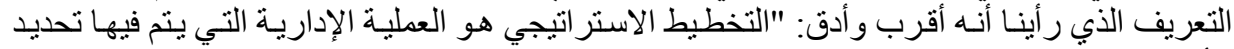

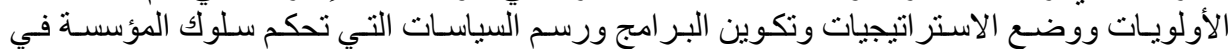

استخدام المو ارد المختلفة الماديـة و البشرية لتحقيق أهدافها" (محمود عبد اللطيف موسى، 2010،

(10)

3.2.2.التزام الإدارة العليا: تلعب الإدارة العليا دورا كبير ا في تحول المؤسسة إلى إدارة الجودة الثاملة،

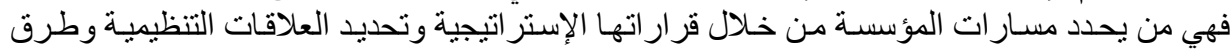

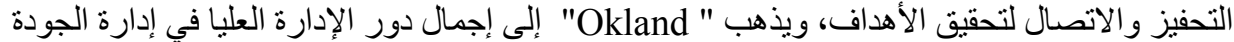

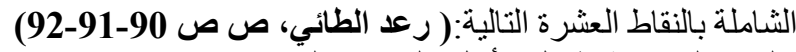

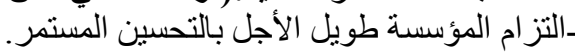
ـ تبني فلسفة المعيب صفر لتنغيير الثقافة التنظيمية باتجاه انجاز العمل بصورة صحيحة من أول مرة من

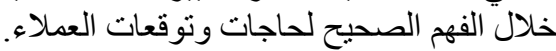

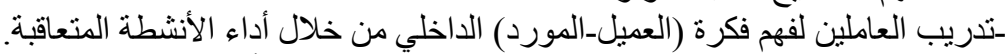

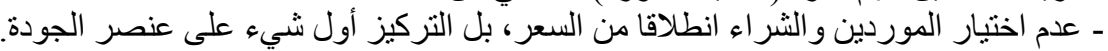

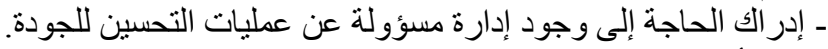

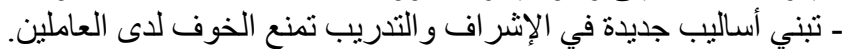

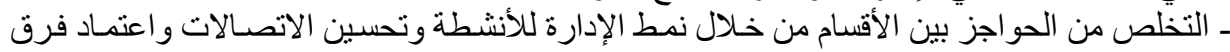

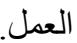

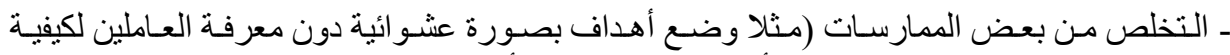

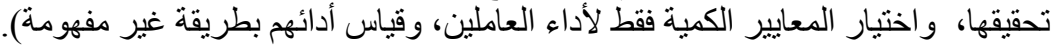

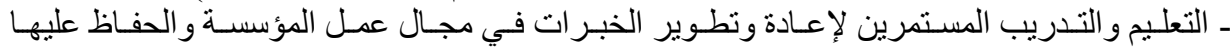
و إثر اكها في اتخاذ القرار التمات. ـ ـ اعتماد منهج منظم لإدارة عملية التنفيذ لإدارة الجودة الثار الثاملة.

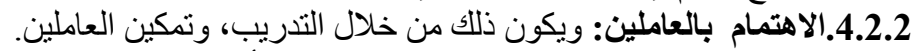

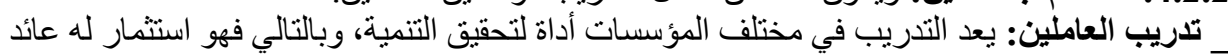

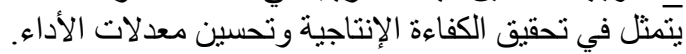

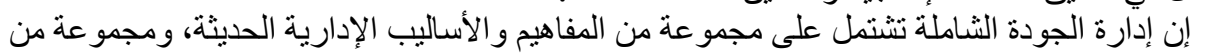

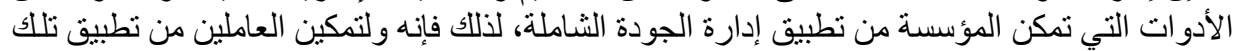

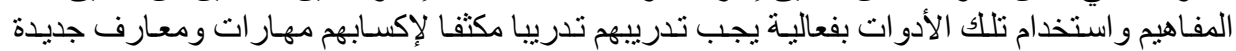

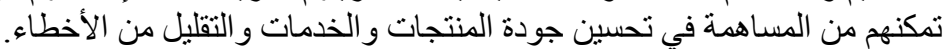

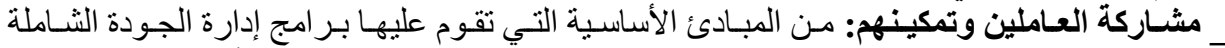

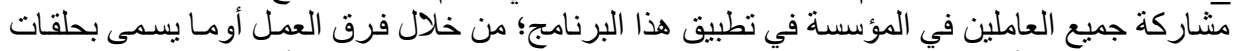

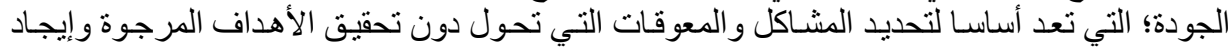




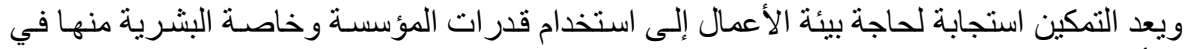

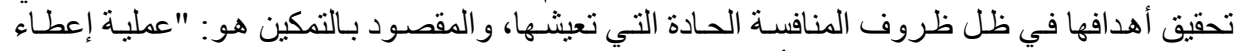

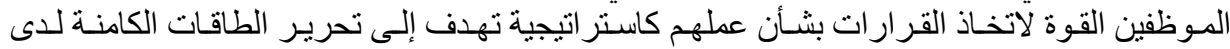

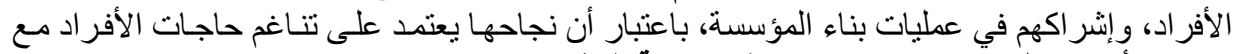

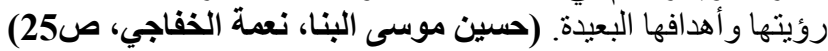
التركيز

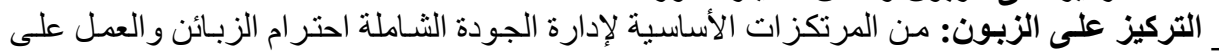

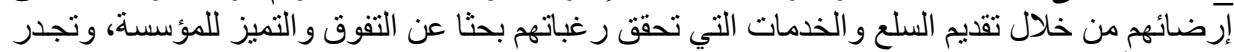

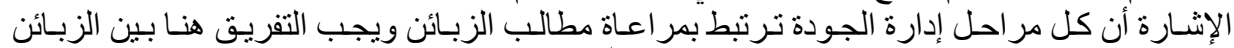

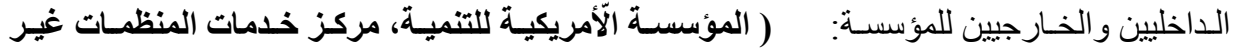

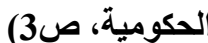

أ_الزبائن الداخليين: وهم أعضاء مجالس الإدار ات و الجهاز التنفيذي و العاملون بالمؤسسـة، فكل و واحد

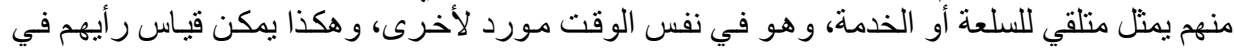

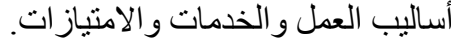
بـ الزبائن الخارجيين: وهم الجمهور المتلقي لخدمات أو منتجات المؤسسة من المحيط الخـارجي، فهم يمثلون الفئات المستهدفة.

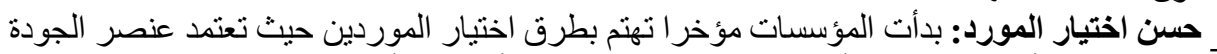

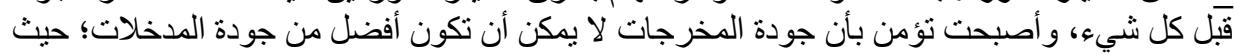

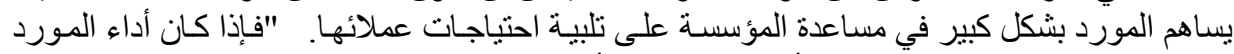

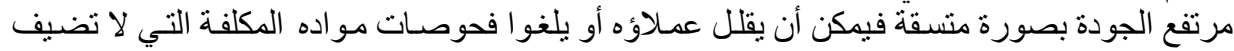

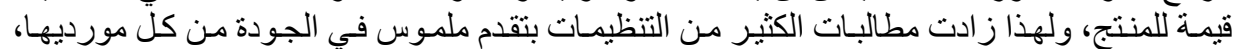

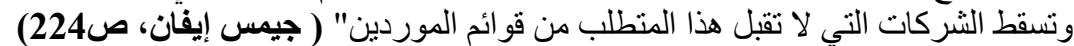

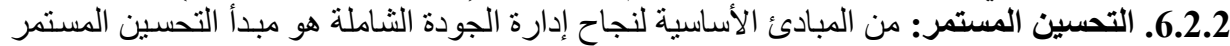
الذي يعطي للمؤسسة التفوق و التميز باستمر ار على منافسيها، و وعلية التحسين هذه التهارة عملية شاملة يقوم بها

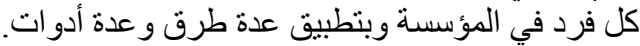

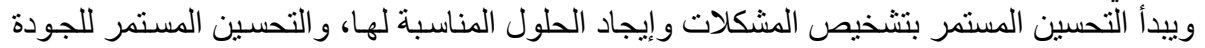

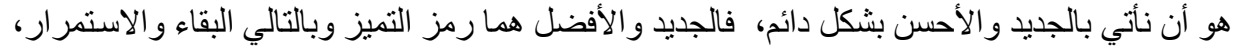

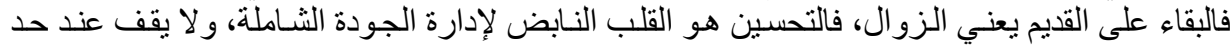

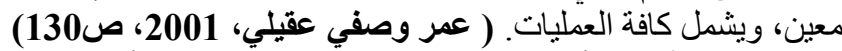

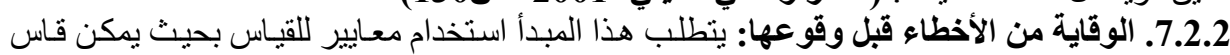

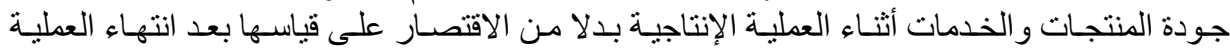
الإنتاجية وبعد وقود المنوات الأخطاء.

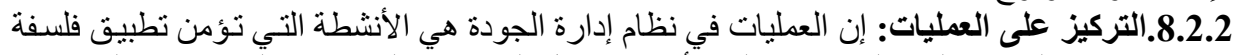

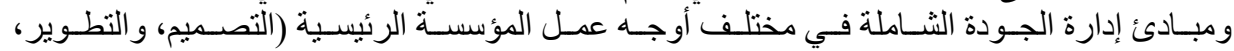

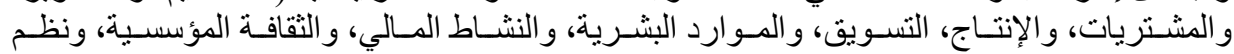

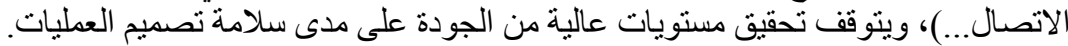

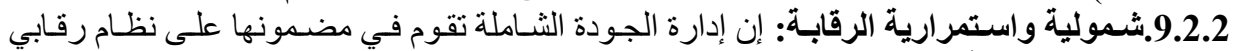

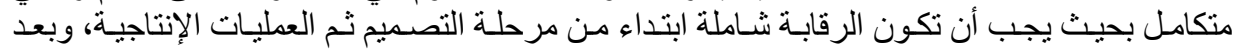
الانتهاء من العمليات الإنتاجية، ثم تستمر إلى مانى ما بعد البيع.

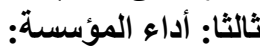
إن الأهمية التي اكتسبها موضواءو الدوع الأداء في المؤسسات الاقتصادية جعل من اللازم الخوض في مدلوله كمصطلح، إذ يجب تحديد مفهومه وضبط مدلّوله. 
1. مفهوم الأداء: بشكل عام أصبح تحديد المعلمات لثرح الأداء عمومـا والأداء التتظيمي بشكل خاص

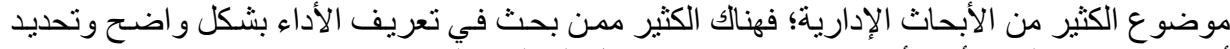

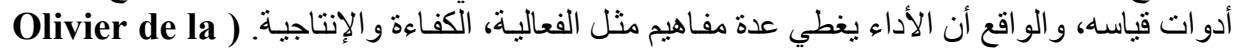
(villarmai, Avril 2001, p01

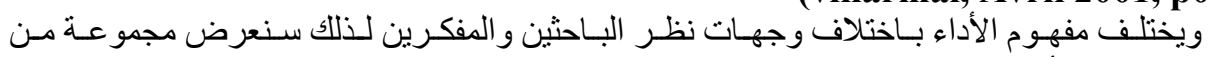

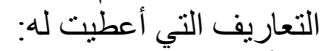

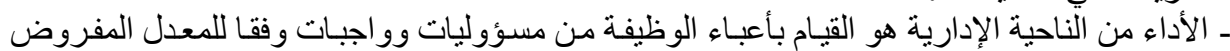

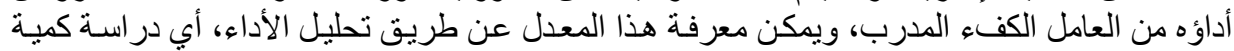

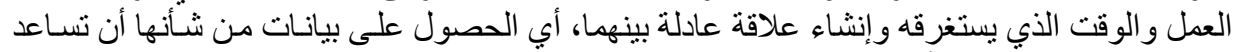

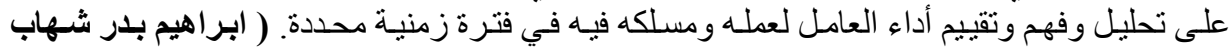

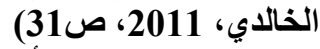

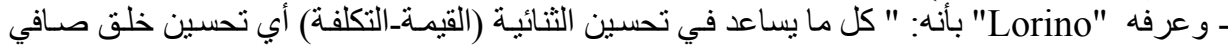

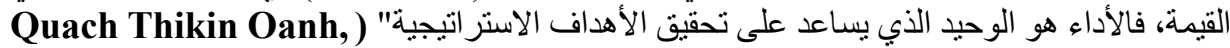

(2006,p3.

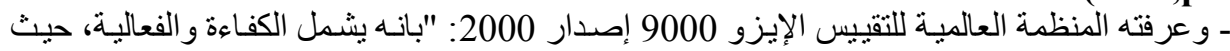

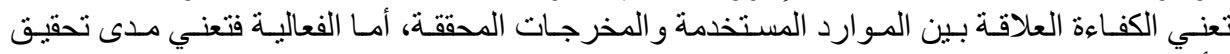

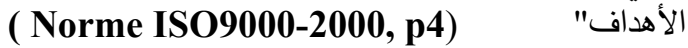

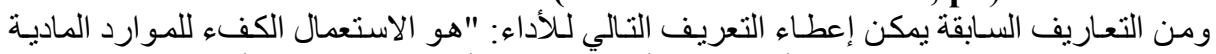

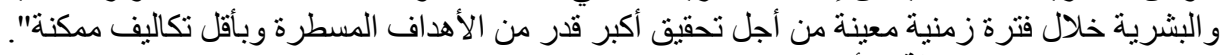

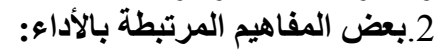

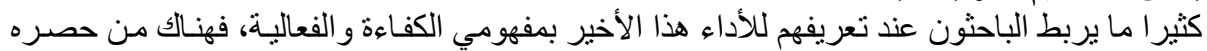

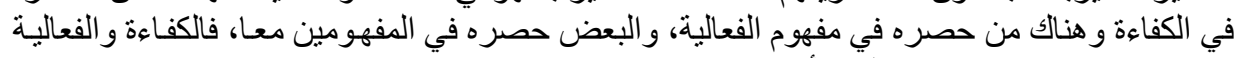

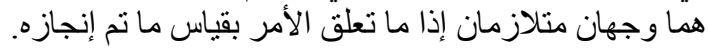

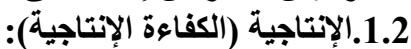

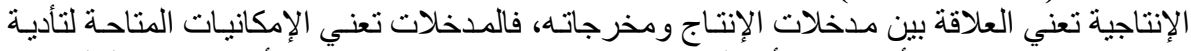

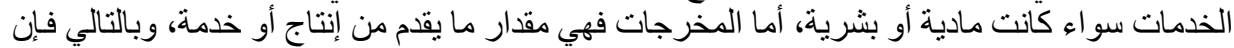

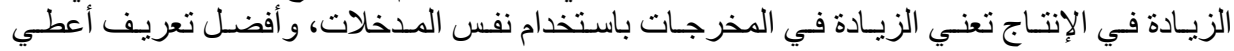

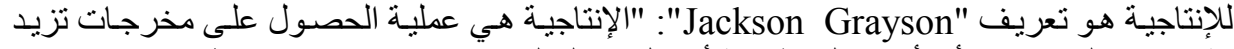

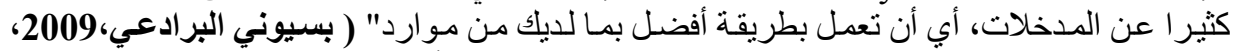

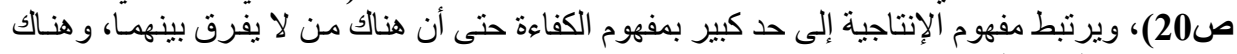

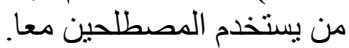

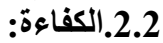

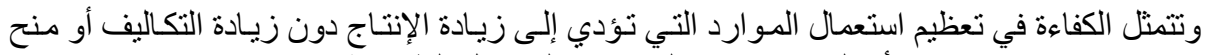

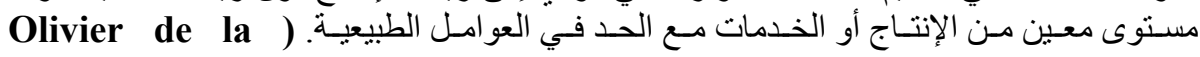
(villarmois,2001 p01 وتثير الكفاءة إلى الطريقة الاقتصادية التي ينت بها إنجاز العمليات المتعلقة بالأهداف و عادة مـا يعبر

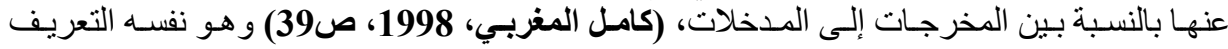

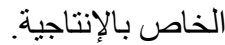
وحسب "Vincent plauchet" الكفاءة هي:"القدرة على إنجاز العمل المطلوب بأقل الإمكانيات،

و النشاط الكفء هو النشاط الأقل تكلفة". (Vincent plauchet, 2006, p7)

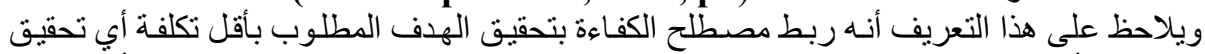
المخرجات بأقل مدخلات و هو لا يختلف كثير التعن تعريف الإنتاجية، وبالتالي يمكن استتناج أن الكفاءة 
و الإنتاجية هما وجهان لعملة واحدة و لا يمكن التفريق بينهما، فهنالك من بيتخدم أحد المفهومين كبديل عن الآخر أو جعلوما متلازمين باستخدام مصطلح الكان الكفاءة الإنتاجية.

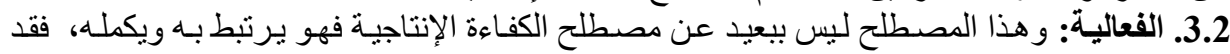

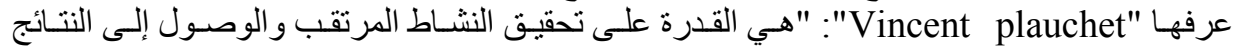

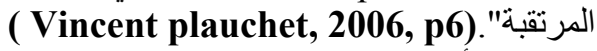

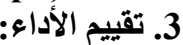

يمكن تعريف تقييم الأداء بأنه قياس الأداء الفعلي ومقارنة النتائج المحققة بالمعايير التي سبق تحديدها

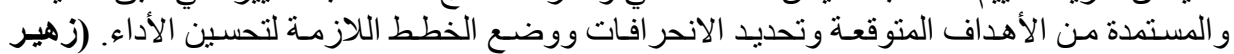

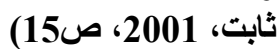

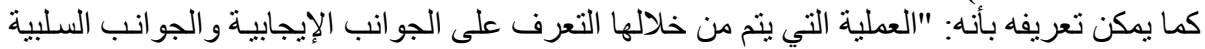

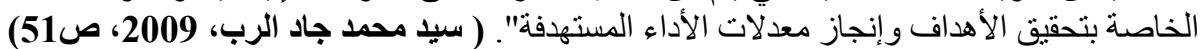

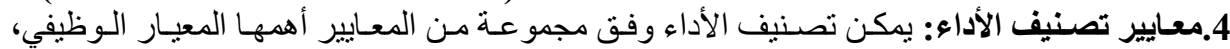

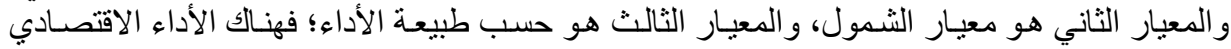

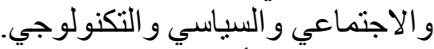

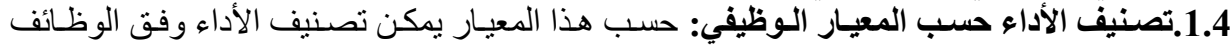

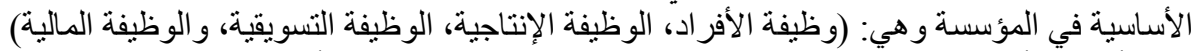

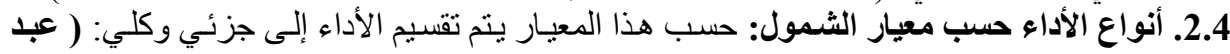

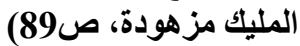

3.4.أنواع الأداء حسب صلألطبيعة: حسب هذا المعيار ينم تقسيم الأداء إلى اجتماعي و اقتصادي.

رابعا: تحليل بيانات الاستبيان:

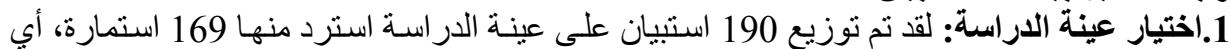

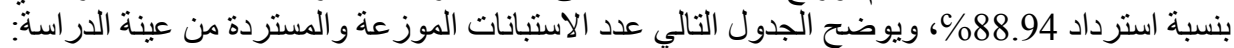

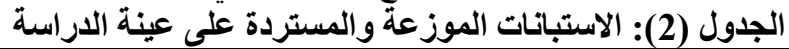

\begin{tabular}{|c|c|c|c|c|c|}
\hline للاستهــــــائتي & 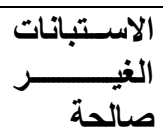 & الاسترداد & المستردة الاستباتات & الموزعتبانتات & المؤسسات \\
\hline 53 & 2 & 91.66 & 55 & 60 & مركب تمييع الغاز الطبيعي \\
\hline 49 & 6 & 91.66 & 55 & 60 & مركب تكرير البترول \\
\hline 27 & 0 & 90 & 27 & 30 & مركب المواد البلاستيكية \\
\hline 10 & 0 & 100 & 10 & 10 & مركب تكرير النفط المكثف \\
\hline 30 & 0 & 100 & 30 & 30 & بالأنابيريبـة الجهويـة للنقــل \\
\hline 169 & 8 & 93.15 & 177 & 190 & المجموع \\
\hline
\end{tabular}

2. 2.الأساليب الإحصائية المستخدمة: من أجل تحقيق أهداف الدر اسة وتحليل بياناتها تم استخدام مجمو عة من الأساليب الإحصائية بالاعتماد

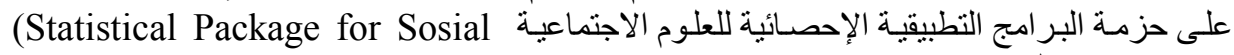
Science) وفيما يلي أهم الأساليب الإحصائية المستخدمة: 1.2. أساليب الإحصاء الوصفي: وتلإئلت في التكر ارات و النسب المئوية، المتوسط الحسابي، الانحر اف

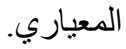


2.2.أساليب الإحصاء الاستدلالي: وتمثلت في: معامل ألفا كرونباخ لاختبار ثبات أداة الدر اسـة، معامل

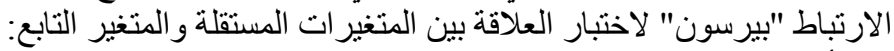

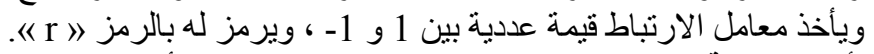

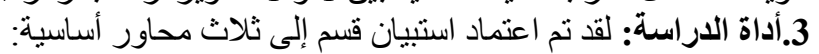

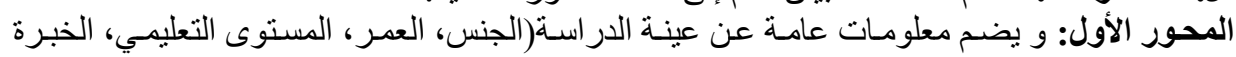

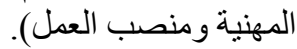
المحور الثاني: ويضم اليبانات الخاصة بمبادئ إدارة الجودة الثاملة (التزام ام الإدارة العليا، ثقافة الجودة،

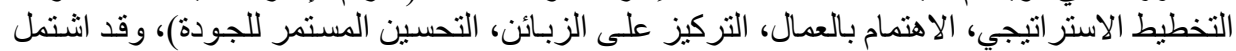
على 43 عبارة. المحور الثالث: تضمن البيانات الخاصة بالمتغير التابع (الأداء)، وتضمن 13 عبارة أخذت الأرقام من 44

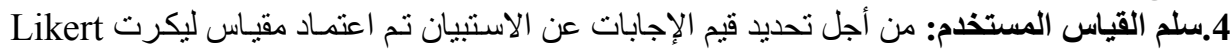

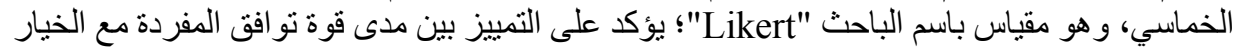

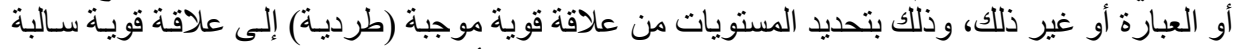

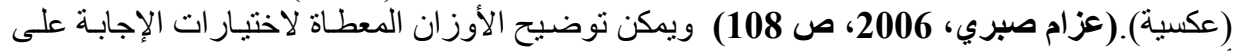

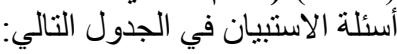
الجدول (3): درجات سلم ليكرت الخماسي الخي

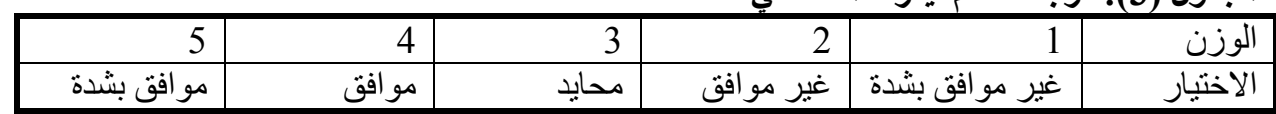

ويتم تحليل إجابات مفردات العينة من خلال الوسط الحسابي، والذي يمكن أن أن يقع بالنسبة لمقياس

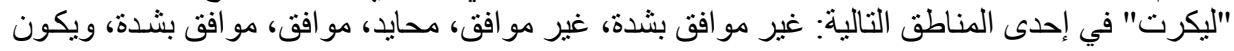

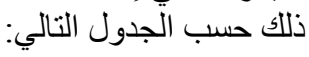

الجدول (4): طول الفئات حسب مقياس "ليكرت" الخماسي

\begin{tabular}{|c|c|c|}
\hline الاتجاه (درجة المو افقة) & الرأي & المتوسط الحسابي \\
\hline تميل الإجابات إلى (غير مو افق بشدة- منخفضة جدا) & غير مو افق بشدة & 1 إلى أقل من 1.80 \\
\hline تميل الإجابات إلى (غير موافق_منخفضة) & غير موافق & 1.80 إلى أقل من 2.60 \\
\hline تميل الإجابات إلى (محايد-متوسطة) & محايد & 2.60 إلى أقل من 3.40 \\
\hline تميل الإجابات إلى (مو افق-مرتفعة) & 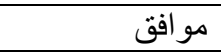 & 3.40 إلى أقل من4.20 \\
\hline تميل الإجابات إلى (مو افق بشدة_مرتفعة جدا) & مو افق بشدة & 4.20 إلى أقل من 5 \\
\hline
\end{tabular}
المصدر: من إعداد الباحثة بناء على ماسبق

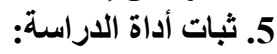

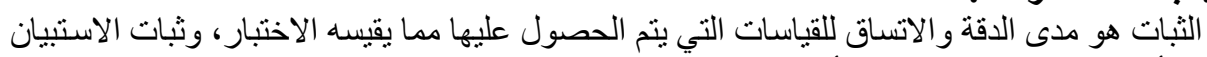

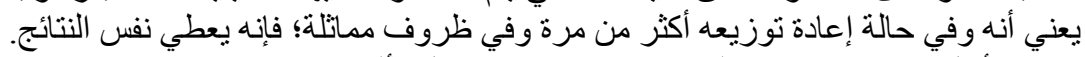

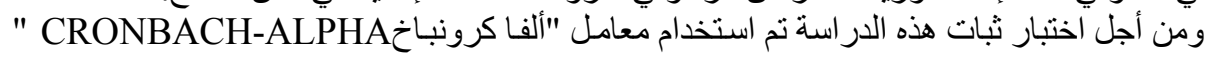

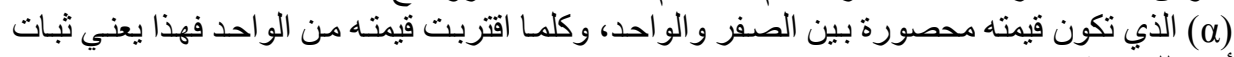

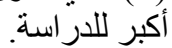
و الجدول التالي يوضتح معاملات ثبات أداة الدر اسـة للمتغير ات المستقلة كل على حدى، ثم للمتغير المستقل الرئيسي، ثم للمتغير التابع، ثم للاستبيان ككل. 
دور تطبيق مبادئ الجودة الشاملة في تحسين أداء المؤسسة دراسة حالة قطب المحروقات بسكيكدة

الجدول (5): معاملات ثبات أداة الدراسة

\begin{tabular}{|c|c|c|c|}
\hline مستوى المقياس & معامل الثبات a & عدد العبارات & المتغير \\
\hline ميتاز & 0.850 & 6 & التز ام الإدارة العليا \\
\hline ممتاز & 0.819 & 8 & ثقافة الجودة \\
\hline 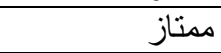 & 0.880 & 7 & التخطيط الاستر اتيجي \\
\hline مثتاز & 0.824 & 9 & الاهتمام بالعمال \\
\hline ممتاز & 0.812 & 6 & التركيز على الزبائن \\
\hline مثتاز & 0.862 & 7 & التحسين المستمر للجودة \\
\hline ممتاز & 0.889 & 43 & المتغير المستقل الرئيسي \\
\hline ميتاز & 0.870 & 13 & المتغير التابع \\
\hline ممتاز & 0.956 & 56 & الاستبيان ككل \\
\hline
\end{tabular}

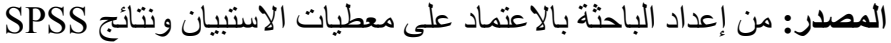

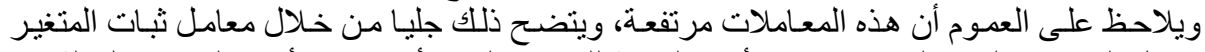

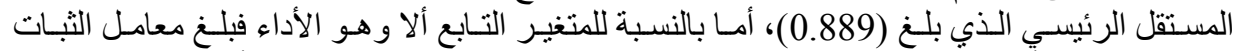

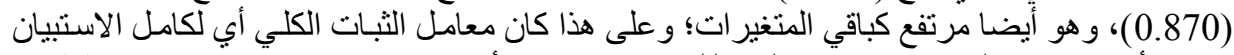

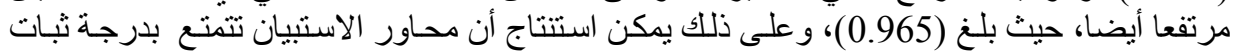

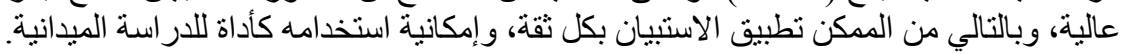
6. 1. عرض وتحليل نتائج الاستبيان:

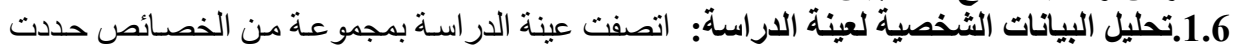

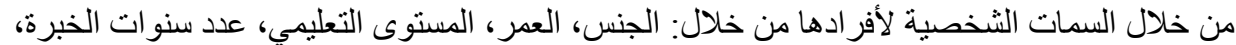

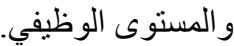

الجدول (6): توزيع أفراد العينة حسب الخصائص الثخصية

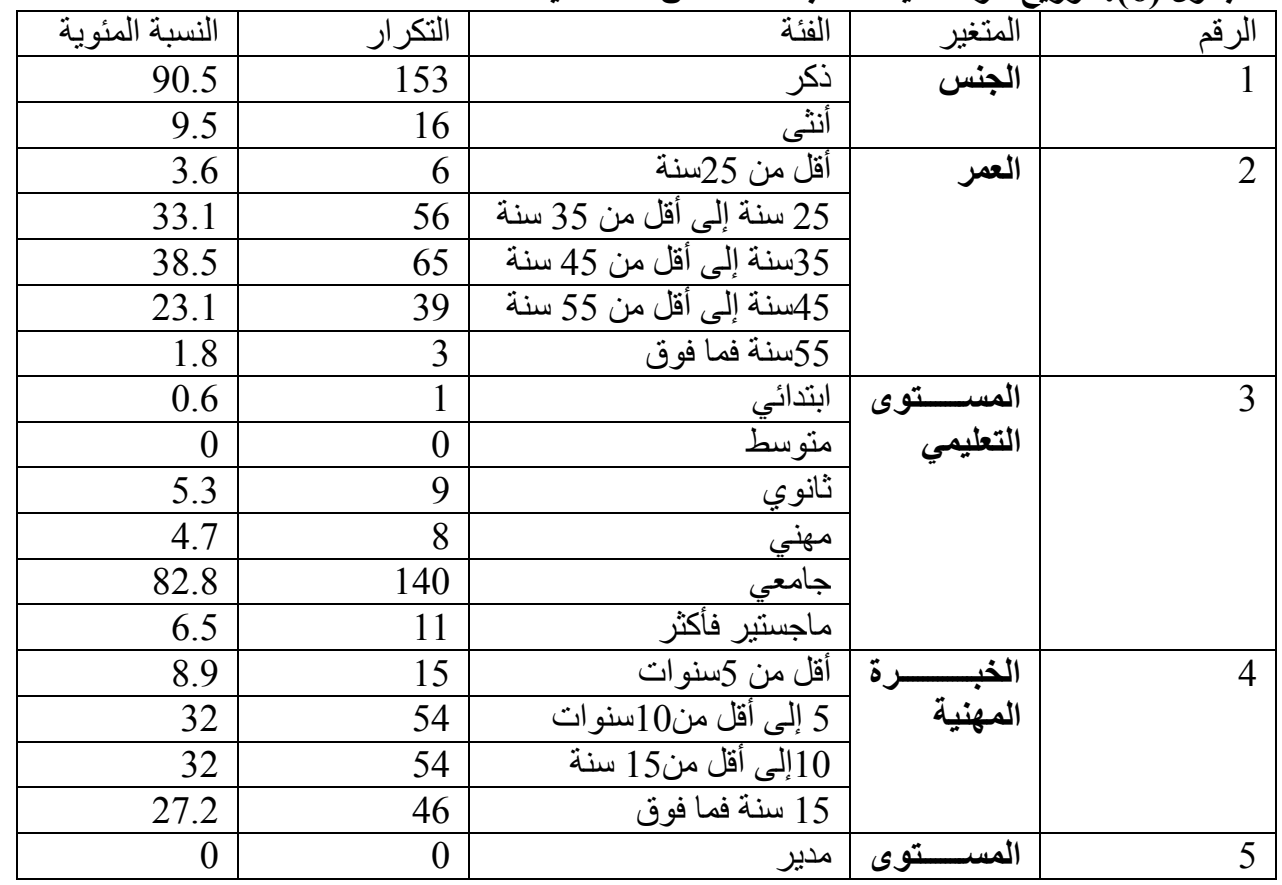




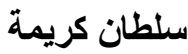

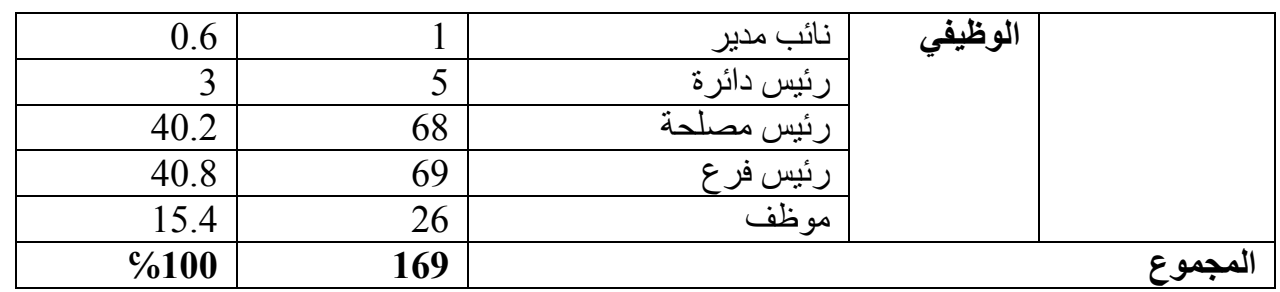

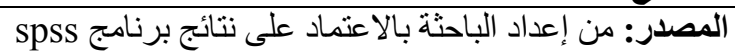

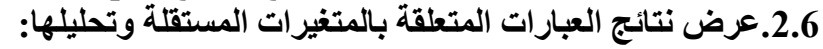

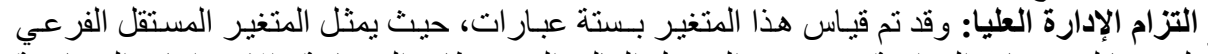

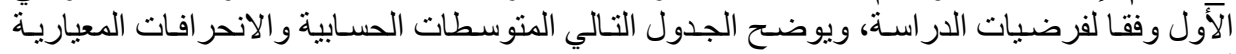

الجدول (7): المتوسطات الحسابية والاتحر افات المعيارية لمتفير التزام الإدارة العليا

\begin{tabular}{|c|c|c|c|c|c|}
\hline الموافقة & ألهميــــة & المعباري اف & الحسابيـ الحتبـ & العبار ات & رالعبارة \\
\hline متوسطة & 4 & 1.02 & 3.38 & 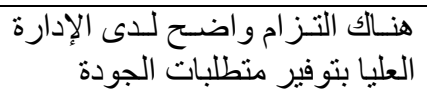 & 1 \\
\hline منوسطة & 6 & 0.92 & 3.32 & 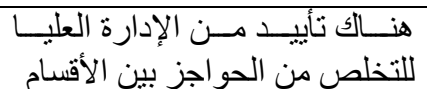 & 2 \\
\hline متوسطة & 5 & 0.98 & 3.37 & 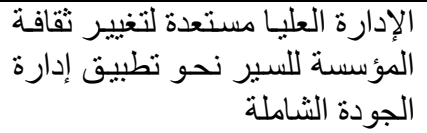 & 3 \\
\hline مرتفعة & 3 & 0.96 & 3.47 & برنامج الجز امدة الإدارة العليا بتأييد & 4 \\
\hline مرتفعة & 2 & 0.95 & 3.60 & تضنمع الإدارة العليا مقاييس عاتهالمية & 5 \\
\hline 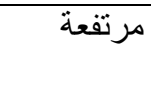 & 1 & 0.93 & 3.65 & تقوة الإدارة العليا بمر اقبة مستوى & 6 \\
\hline مرتفعة & & 0.73 & 3.47 & حسابي والاتحر اف المعياري العام & | المتوسط إ \\
\hline
\end{tabular}

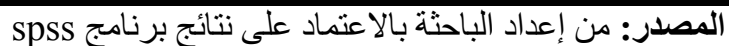

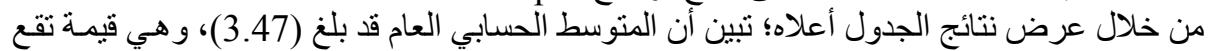

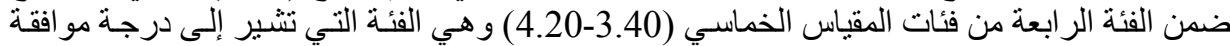

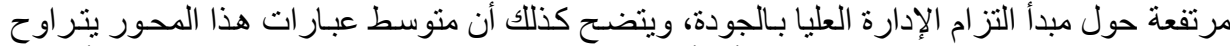

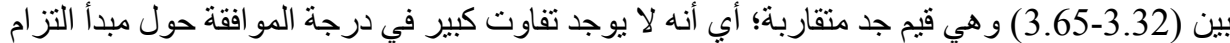

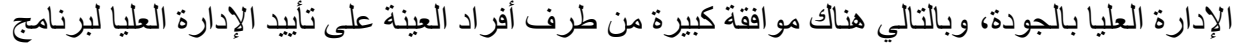

ثقافة الجودة: وقد تم قياس هذا المتغير بـثماني عبـار ات، حيث يمثنل المتغير المستقل الفرعي الثناني

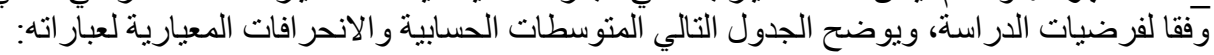


الجدول (8): المتوسطات الحسابية والاتحر افات المعيارية لمتغير ثقافة الجودة

\begin{tabular}{|c|c|c|c|c|c|}
\hline دالموافقة & أهمبِ ألعبارة & الالانحــراف & الحستوسيـــ اط & العبار ات & رالعبارة \\
\hline متوسطة & 8 & 1.04 & 2.94 & 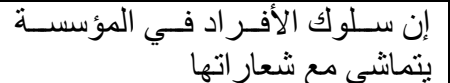 & 7 \\
\hline مرتفعة & 1 & 1.01 & 3.90 & 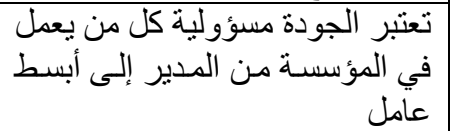 & 8 \\
\hline متوسطة & 5 & 1.08 & 3.18 & 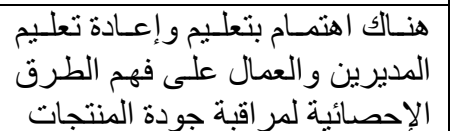 & 9 \\
\hline متوسطة & 7 & 1.13 & 3.00 & تستخدم الإدارة الأسلوب العلمي في العمل & 10 \\
\hline متوسطة & 3 & 0.97 & 3.33 & وروح الفريق العمل جو الانسـام و التفـاهم & 11 \\
\hline متوسطة & 6 & 1.01 & 3.07 & 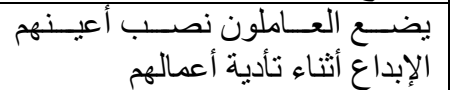 & 12 \\
\hline متوسطة & 4 & 1.12 & 3.20 & تئدية أعمالهم العـاملون بـاحتر ام الوقت في & 13 \\
\hline مرتفعة & 2 & 1.01 & 3.72 & 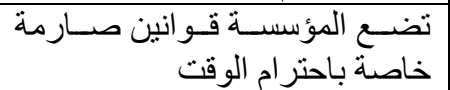 & 14 \\
\hline متوسطة & & 0.69 & 3.29 & لحسابي والانحراف المعياري العام & 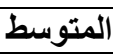 \\
\hline
\end{tabular}

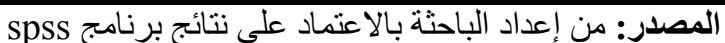

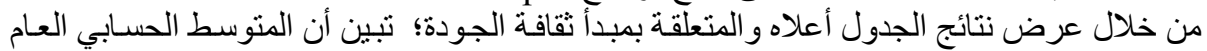

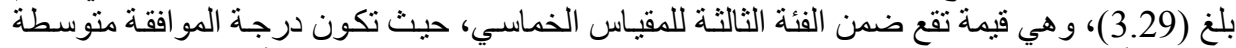

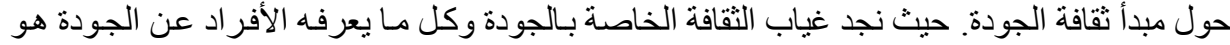

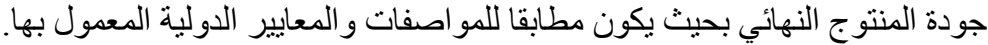
التخطيط الاستر اتيجي للجودة: وقد تم قياس هذا المتغير بسبعة عبار ات، ويمثل هذا المتغير التير المتغير

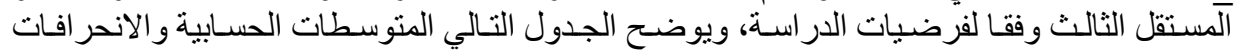
المعيارية لعبار ات هذا المتغير : لمنيات 
سلطان كريمة

الجدول (9): المتوسطات الحسابية والاتحرافات المعيارية لمتغير التخطيط الاستراتيجي للجودة المئرة

\begin{tabular}{|c|c|c|c|c|c|}
\hline المو افقة & ألعمبِ & 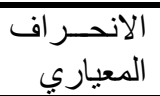 & الحستوســــــ الحسب & | ل العبار ات & رالعبارة \\
\hline متوسطة & 2 & 1.02 & 3.27 & 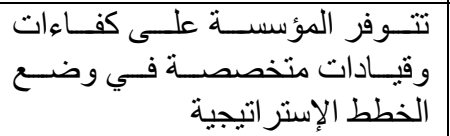 & 15 \\
\hline متوسطة & 5 & 1.02 & 3.18 & 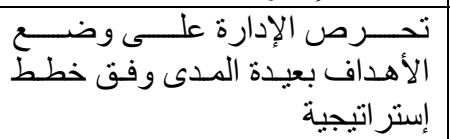 & 16 \\
\hline متوسطة & 4 & 1.07 & 3.20 & 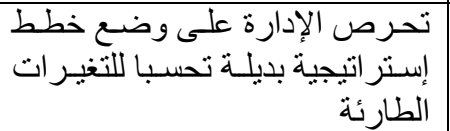 & 17 \\
\hline متوسطة & 2 & 0.96 & 3.27 & 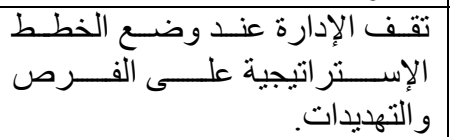 & 18 \\
\hline متوسطة & 7 & 1.13 & 2.63 & قبتم الأخذ بر أي العمـال و اقتر احساتهم & 19 \\
\hline متوسطة & 6 & 1.09 & 2.89 & 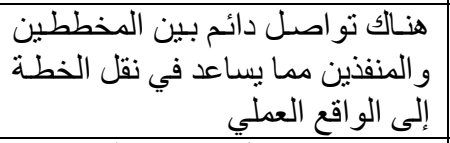 & 20 \\
\hline مرتفعة & 1 & 0.99 & 3.40 & 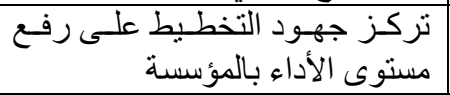 & 21 \\
\hline متوسطة & & 0.79 & 3.12 & الحسابي والانحر اف المعياري العام & المتوسش \\
\hline
\end{tabular}

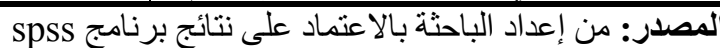

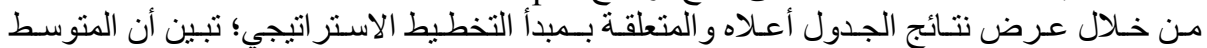

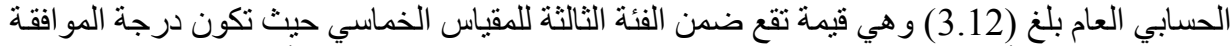

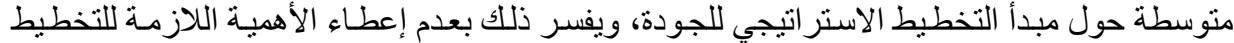

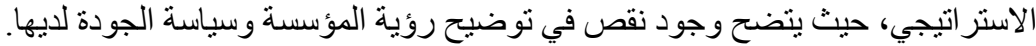

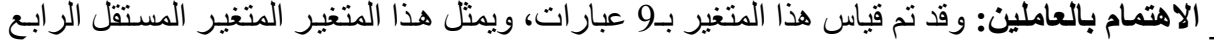

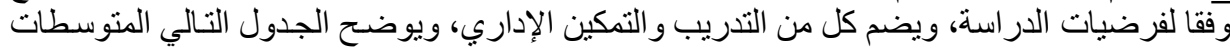
الحسابية و الانحر افات المعيارية لعبار ات هذا التنغير : 
الجدول (10): المتوسطات الحسابية والانحر افات المعيارية لمتغير الاهتمام بالعمال

\begin{tabular}{|c|c|c|c|c|c|}
\hline دالموافقة & أهمبِ العبـة & الانحسيـر افي & 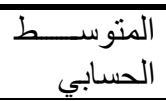 & العبار ات & رقارة \\
\hline متوسطة & 6 & 1.06 & 3.24 & 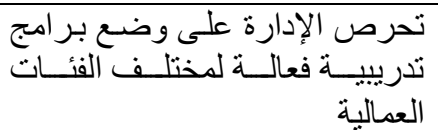 & 22 \\
\hline متوسطة & 7 & 1.22 & 3.08 & 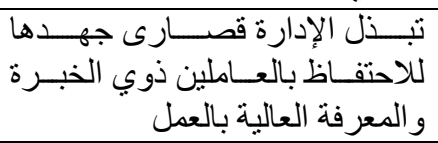 & 23 \\
\hline مرتفعة & 5 & 1.22 & 3.46 & 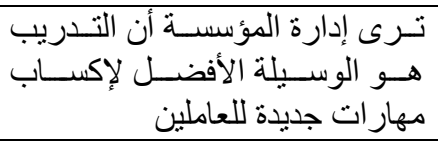 & 24 \\
\hline متوسطة & 9 & 0.02 & 2.88 & العاملين والإدارة اتصـال مباثـر وفــال بـين & 25 \\
\hline مرتفعة & 2 & 1.01 & 3.69 & 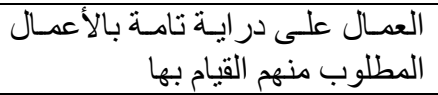 & 26 \\
\hline متوسطة & 11 & 0.91 & 2.83 & أعمالكه العمال كل الحريـة في إنجاز & 27 \\
\hline متوسطة & 8 & 1.11 & 3.07 & 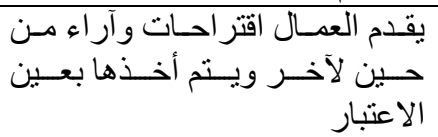 & 28 \\
\hline مرتفعة & 1 & 0.88 & 3.77 & 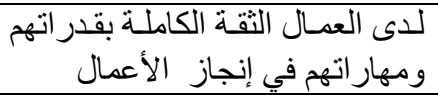 & 29 \\
\hline مرتفعة & 4 & 1.74 & 3.54 & 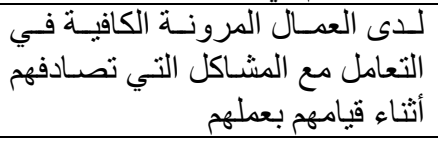 & 30 \\
\hline منوسطة & & 0.62 & 3.20 & حسـابي والانحر اف المعياري العام & المتوسط \\
\hline
\end{tabular}

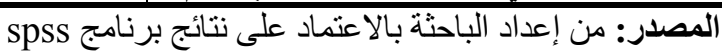

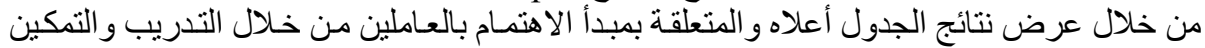

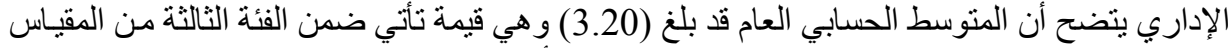

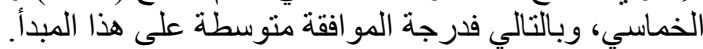

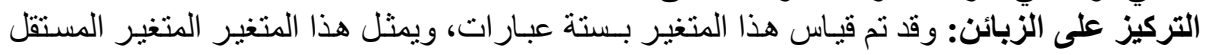

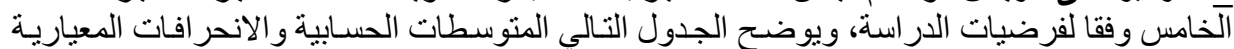

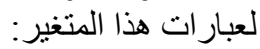


سلطان كريمة

الجدول (11): المتوسطات الحسابية والانحر افات المعيارية لمتغير التركيز على الزبائن

\begin{tabular}{|c|c|c|c|c|c|}
\hline درجة المقافة & أهمبــــارة & الالنحــر افيـاري & 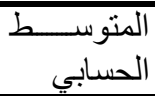 & العبار ات & رقارة \\
\hline متوسطة & 6 & 1.21 & 2.80 & 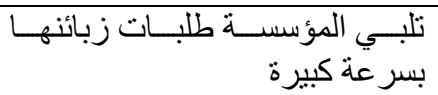 & 31 \\
\hline متوسطة & 5 & 1.12 & 2.86 & 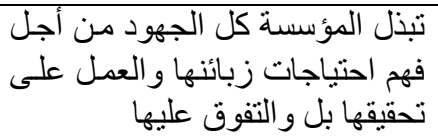 & 32 \\
\hline متوسطة & 2 & 0.96 & 3.27 & 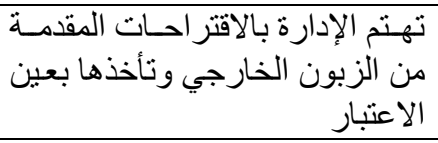 & 33 \\
\hline متوسطة & 4 & 0.85 & 3.18 & 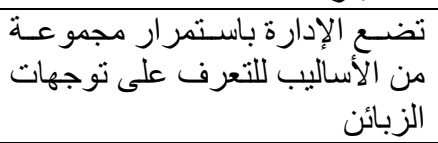 & 34 \\
\hline متوسطة & 1 & 0.89 & 3.30 & 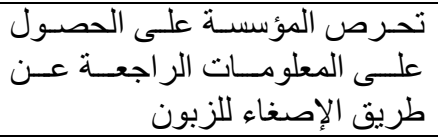 & 35 \\
\hline متوسطة & 3 & 0.96 & 3.24 & 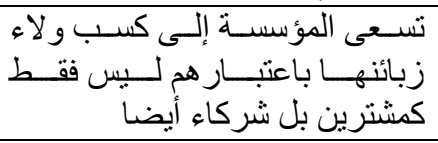 & 36 \\
\hline متوسطة & & 0.72 & 3.11 & حسابي والانحر اف المعياري العام & المتوسد \\
\hline
\end{tabular}

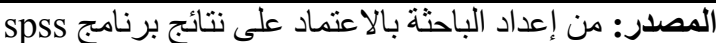

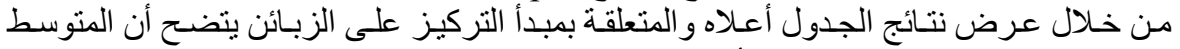

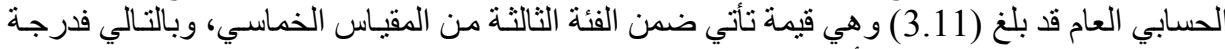
المو افقة منوسطة على على هذا المبدأ.

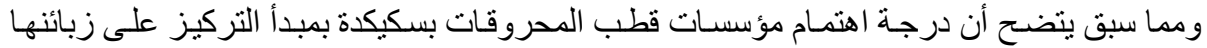

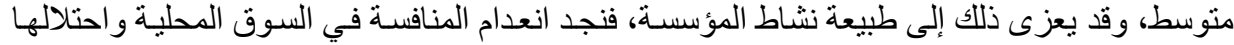
مكانة هامة في السوق العالمية.

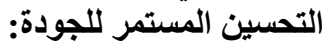

آلجدول (12): المتوسطات الحسابية والانحرافات المعيارية لمتغير التحسين المستمر للجودة

\begin{tabular}{|c|c|c|c|c|c|}
\hline الموافقة & أهمبـــــة & الالمعياريـر اف & 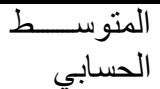 & العبار ات & رقارة \\
\hline متوسطة & 3 & 1.01 & 3.26 & 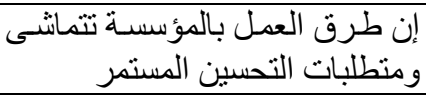 & 37 \\
\hline متوسطة & 5 & 1.01 & 3.17 & 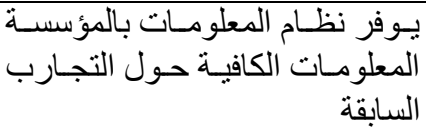 & 38 \\
\hline مرتفعة & 2 & 0.98 & 3.51 & 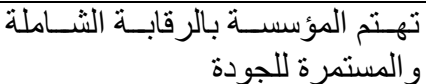 & 39 \\
\hline متوسطة & 7 & 0.98 & 3.14 & 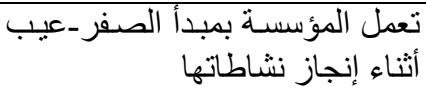 & 40 \\
\hline
\end{tabular}


دور تطبيق مبادئ الجودة الشاملة في تحسين أداء المؤسسة دراسة حالة قطب المحروقات بسكيكة

\begin{tabular}{|c|c|c|c|c|c|}
\hline مرتفعة & 1 & 0.90 & 3.60 & تونتم المؤسسة بتشخيص المشول المناسبة لهات & 41 \\
\hline متوسطة & 4 & 0.98 & 3.18 & 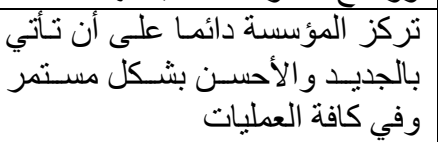 & 42 \\
\hline متوسطة & 6 & 1.11 & 3.15 & 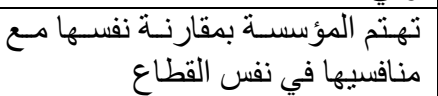 & 43 \\
\hline متوسطة & & 0.74 & 3.29 & \multicolumn{2}{|c|}{ المتوسط الحسابي والاتحر اف المعياري العام } \\
\hline
\end{tabular}

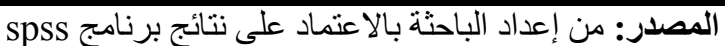

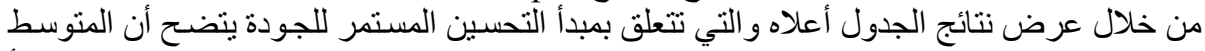

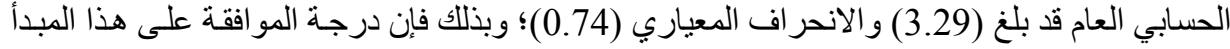

منوسطة.

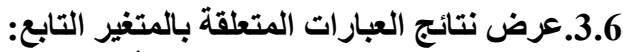

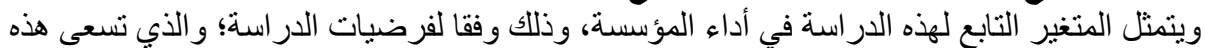

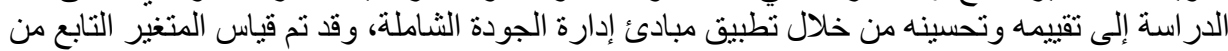

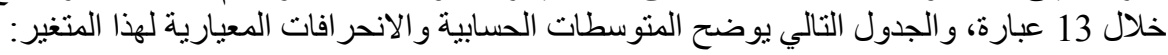

الجدول (13): المتوسطات الحسابية والاتحرافات المعيارية لمتغير الأداء.

\begin{tabular}{|c|c|c|c|c|c|}
\hline دالموافقة & ألهمبـــــة & الانـــــراف & 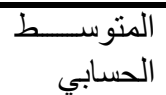 & العبار ات & رقارة \\
\hline مرتفعة & 4 & 0.95 & 3.40 & 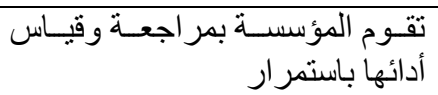 & 44 \\
\hline متوسطة & 11 & 1.02 & 2.95 & 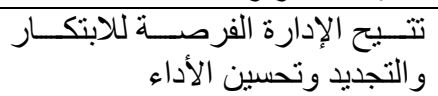 & 45 \\
\hline متوسطة & 6 & 0.98 & 3.25 & تهتخ المؤسسـة بتقليل الإسـر اف في & 46 \\
\hline متوسطة & 7 & 0.95 & 3.19 & 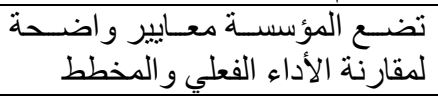 & 47 \\
\hline متوسطة & 5 & 1.03 & 3.26 & 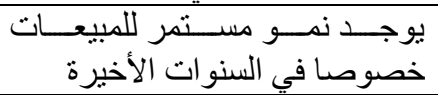 & 48 \\
\hline متوسطة & 9 & 1.12 & 3.08 & 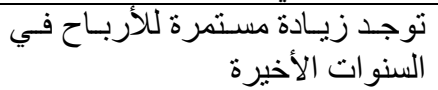 & 49 \\
\hline متوسطة & 8 & 1.03 & 3.17 & 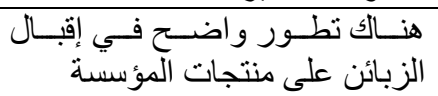 & 50 \\
\hline متوسطة & 10 & 0.88 & 3.01 & 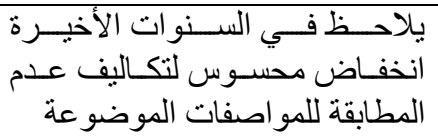 & 51 \\
\hline مرتفعة & 2 & 0.83 & 3.71 & بالثــل الصـاملون على تأديـة عملهم & 52 \\
\hline مرتفعة & 1 & 0.76 & 3.93 & تجنبـ ارتكاب الأخطاء بالمؤسســة علـى & 53 \\
\hline
\end{tabular}




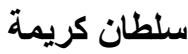

\begin{tabular}{|c|c|c|c|c|c|}
\hline مرتفعة & 3 & 0.93 & 3.57 & يمتلكـ العـاملون المهــار ات الكافيـة الصحيح & 54 \\
\hline منخفضة & 13 & 1.10 & 2.41 & 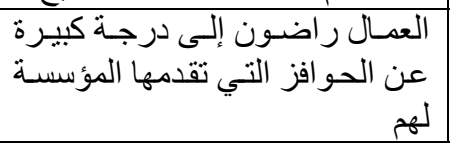 & 55 \\
\hline منخفضة & 12 & 1.10 & 2.49 & 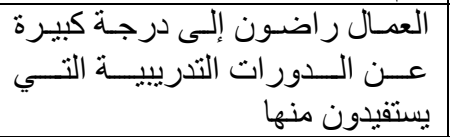 & 56 \\
\hline متوسطة & & 0.59 & 3.19 & الحسـابي والانحر اف المعياري العام & 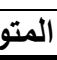 \\
\hline
\end{tabular}

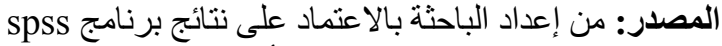

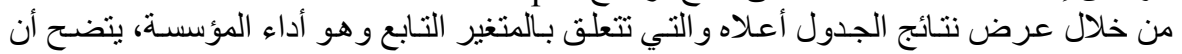

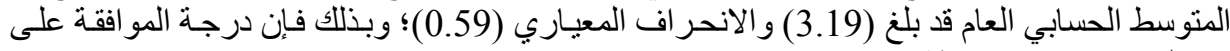
هذا المتغير كانت متوسطة.

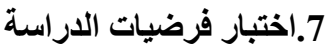

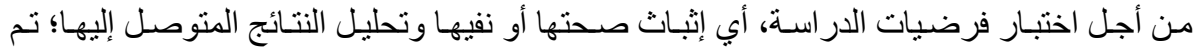
الاعتماد على الحزمة الإحصائية للعلوم الاجتماعية SPSS، واستخدام مجمو علة من الأساليب الإحصائية التي تم ذكر ها سابقا.

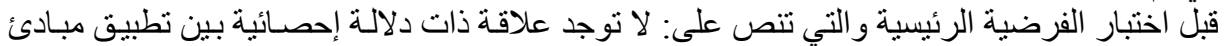

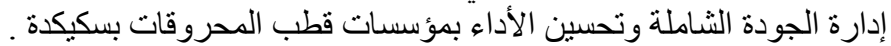
سيتم اختبار فرضياتها الفرعية أو لا؛ حيث سيتم اختبار علاقة الارتباط بين متغير ات الدات الدراسة باستخدام

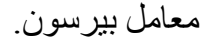
الجدول رقم (14): معامل الارتباط بين مبادئ إدارة الجودة الثشاملة وأداء المؤسسة

\begin{tabular}{|c|c|c|}
\hline مستوى المعنوية & معامل الارتباط & مبادئ إدارة الجودة الشاملة \\
\hline 0.00 & 0.466 & التزام الإدارة العليا بالجودة \\
\hline 0.00 & 0.638 & ثقافة الجودة \\
\hline 0.00 & 0.658 & التخطيط الاستراتيجي \\
\hline 0.00 & 0.701 & الاهتمام بالعمال \\
\hline 0.00 & 0.633 & التركيز على الزيون \\
\hline 0.00 & 0.720 & التحسين المستمر للجودة \\
\hline $\mathbf{0 . 0 0}$ & $\mathbf{0 . 7 8 7}$ & المتغير المستقل الرئيسي (إدارة الجودة الشاملة) \\
\hline
\end{tabular}

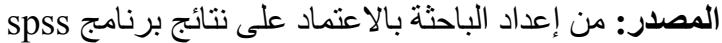

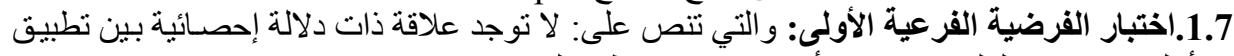

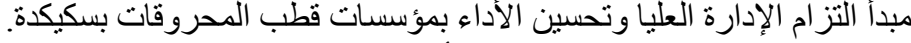

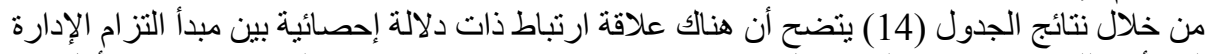

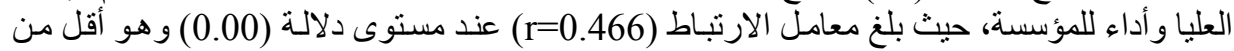

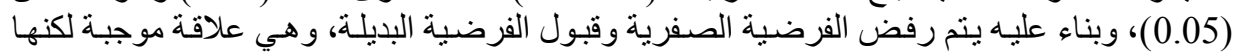

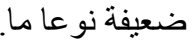

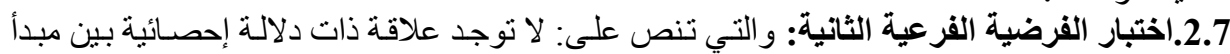

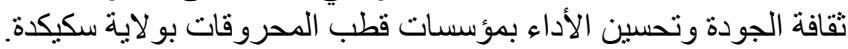

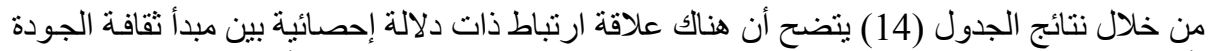

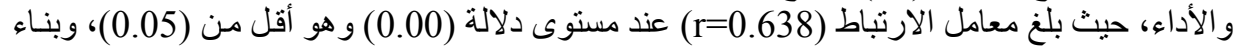

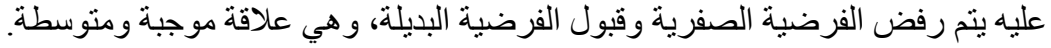


3.7.اختبار الفرضية الفرعية الثالثة: و التي تتص على: " لا توجد علاقة ذات دلالة إحصائية بين تطبيق

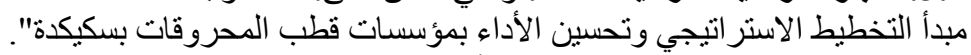

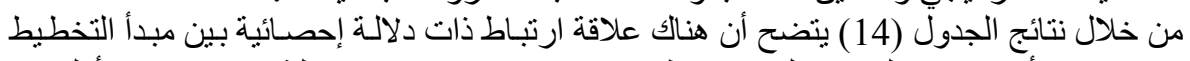

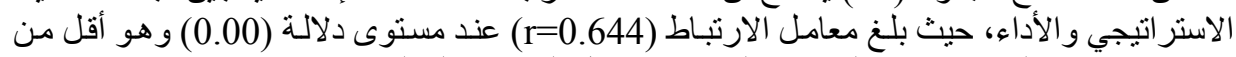

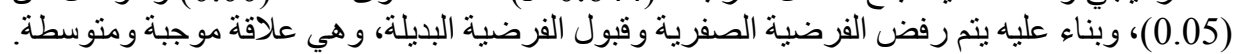

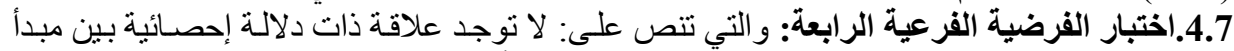

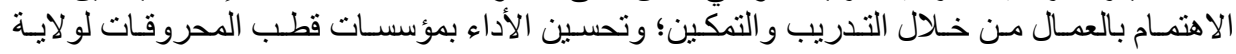

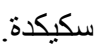

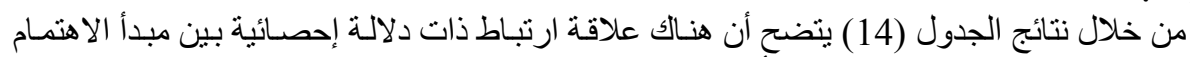

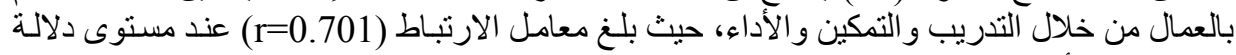

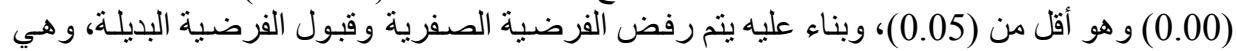
علاقة موجبة وقوية.

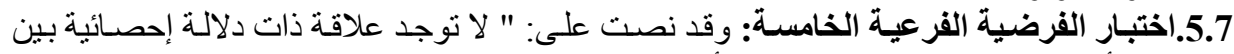

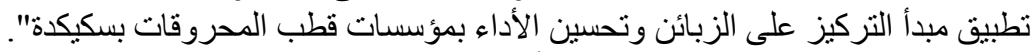

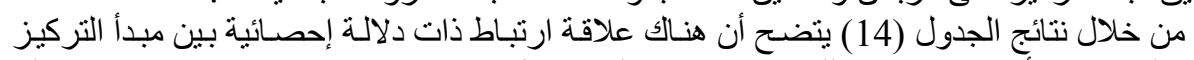

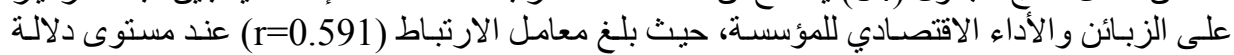

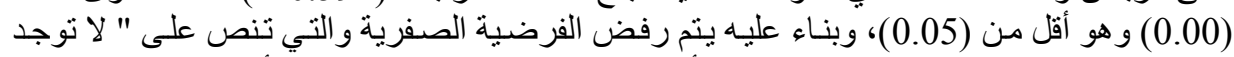

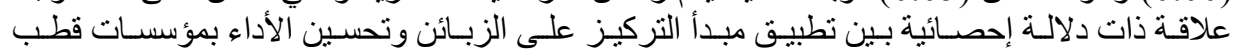

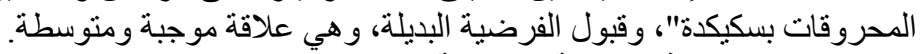

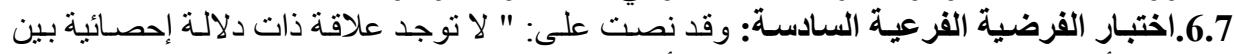

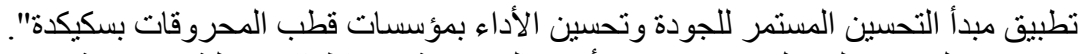

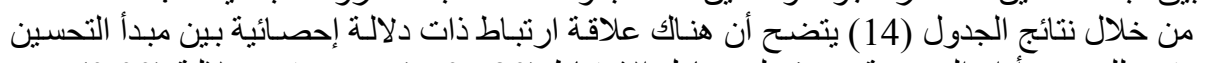

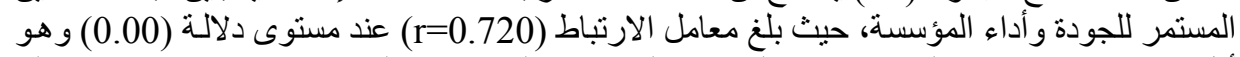

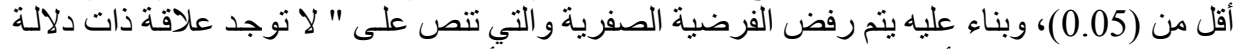

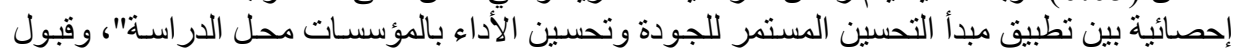

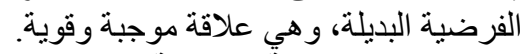
7.7. ملخص الفرضيةة الرئيسية:

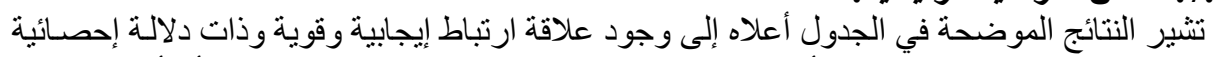

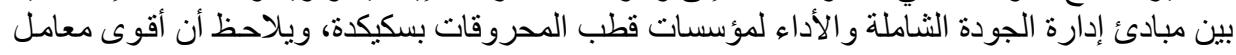

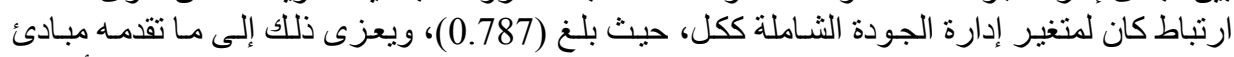

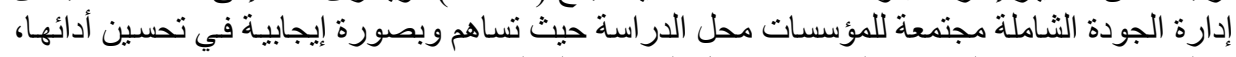
و على هذا ينم رفض الفرضية الفئمة الصفرية وقبول الفرضية البديلة.

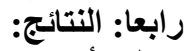

لقد أعدت هذه الدراسـة بهدف تحديد دور مبادئ إدارة الجودة الثـاملة في تحسبين أداء المؤسسـة

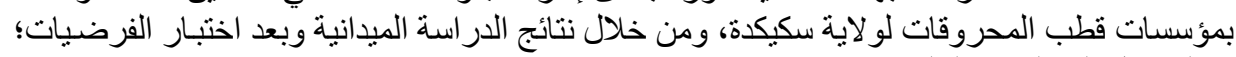
تم التوصل إلى النتائج التالية:

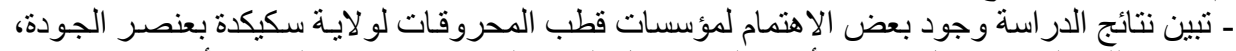

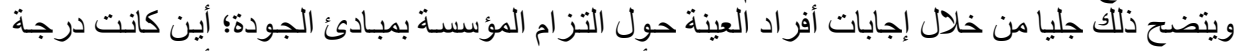

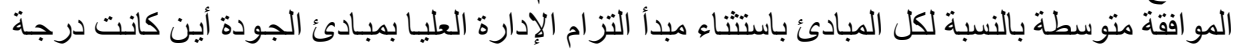

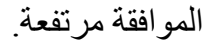
- يبين اختبار فرضيات الدراسة وجود الأبد علاقة ذات دلالة إحصائية بين المتغير ات المستقلة (مبادئ إدارة الجودة الثاملة) و المتغير التنابع (الأداء). 
خامسا: المقترحات: من خلال النتائج المتوصل إلبها يمكن تقديم جملة من المقترحات:

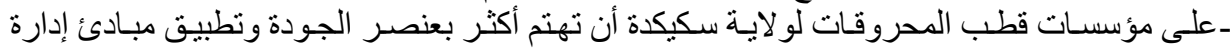
الجودة الثاملة.

- يجب أن تقوم بتحديد مؤشر التهلة لقياس أدائها باستمرار.

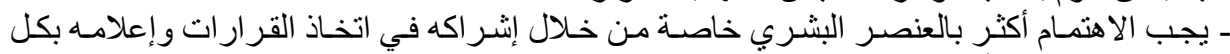

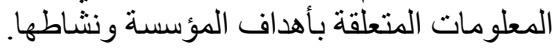

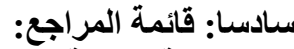

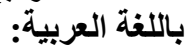

الكتب:

ابر اهيم بدر شهاب الخالدي، معجم الإدارة، الطبعة الأولى، دار أسامة للنشر و التوزيع، عمان، الأردن، 2011.1

2. بسيوني البر ادعي، تنمية مهارات المديرين لزيـادة الإنتاجية وتحسين أداء العـاملين، إيتر الك للنشر والتوزيع، القاهرة، .2009 3. جيمس إيفان، إدارة الجودة الشاملة، ترجمة سرور علي ابراهيم سرور، دار المريخ للنشر، الريـاض 2009.

4. حسين موسى البنا، نعمة الخفاجي، استراتيجية التمكين التنظيمي، دار الأيام للنشر و التوزيع، عمـان، 2014.

5. رعد عبد الله الطـائي ، عيسـى قدادة ،إ.ج.ش، ط العربيـة، دار اليـازوري للنشـر و التوزيـع، عمـان، الأردن،

6. ز هير ثابت، الدليل العملي لمدير القرن 21، كيف تقيم أداء الثركات والعاملين، دار قباء للنشر

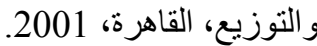

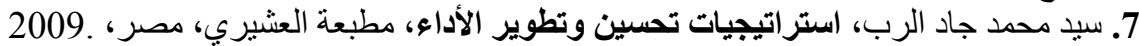

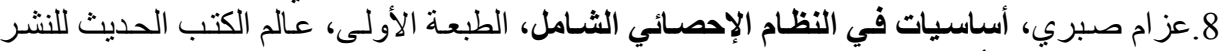

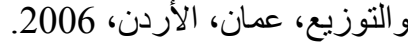

9. عمر وصفي عقيلي، مدخل إلى المنهجيـة المتكاملة لإدارة الجـودة الثـاملة، الطبعة 1، دار و ائلـ للنشر، عمان، الأردن، 2001.

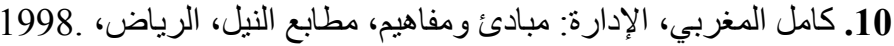

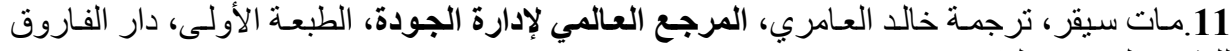

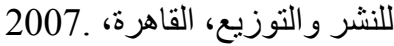
12.محمود عبد اللطيف موسى، التخطيط الاستراتيجي لإدارة الجودة الثاملة في التدريب الإداري ،

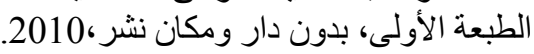

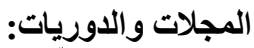

13. المؤسسة الأمريكية للتنمية، مركز خدمات المنظمات غير الحكومية، قياس رضا العمـلاء من أجل فئل

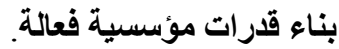

14.عبد المليك مز هودة، الأداء بين الكفاءة والفعالية، مجلة العلوم الإنسانية، العدد الأول، جامعـة محمد فولئ فولة

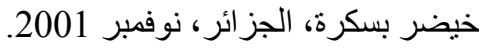

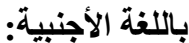

15. Hubert K.Rampersad, total performance scorcard, springer, Paris, 2005 .

16.Joseph M . Juran; Joseph A.Defeo, Juran's quality hand book, « the complete guide to the performance excellence ", sixth edition, MC grawhill, the united states of America, 2010. 


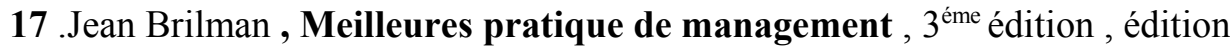
d'organisation, Paris , 2000 .

18. Norme ISO9000-2000, système management de la qualité, principes essentiels et vocabulaire, 2000.

19. Olivier de la villarmais, les cahiers de la recherche, claree, centre lillois d'analyse et de recherche sur l'évolution des entreprises, UPRESACNRS8020, le concept de performance et sa mesures, Avril 2001.

20.Quach Thikin Oanh, une perspective de recherche sur la performance dans l'organisation, $23^{\mathrm{e}}$ colloque annuel de conseil canadian des PMEet de l'entrepreneuriat, trois rivières,canada, 2006.

21.Vincent plauchet, mesure et amélioration des performance industrielles, Tome 24PMF, France 2006. 